\title{
The Effects of Media Co-coverage on Investors' Perceived Relatedness between Two Firms: Evidence from Information Transfers
}

\author{
By: Jingjing Xia
}

\begin{abstract}
This study examines the effects of media co-coverage - a phenomenon where multiple firms are simultaneously mentioned in the same news article—on investors' perceived relatedness between the co-covered firms. Using the setting of information transfers between two co-covered firms during earnings announcements, I find evidence consistent with co-coverage increasing the firms' perceived relatedness. Specifically, the announcement return of the co-covered peer negatively predicts the announcement return of the focal firm following the peer's earnings announcement, suggesting that focal firm investors overreact to the peer's earnings news in information transfers. The negative relationship is stronger when investors are more likely to pay attention to the news article where they were cocovered, and when the peer's earnings are more relevant to the focal firm's upcoming earnings announcement. Further analysis shows that the co-coverage-induced overreaction is stronger when the focal firm has higher uncertainty and when retail investor attention to the focal firm is higher on the peer's announcement day. These findings shed light on an unintended consequence of journalists' cocoverage practice on the efficiency with which equity investors use peer information.
\end{abstract}

\section{JEL codes: G14; G40; M41}

Keywords: media co-coverage; economically related firms; perceived relatedness; information transfers 


\section{Introduction}

Economic decision-making involves comparisons between alternatives, which in the context of the financial market, are often provided by economically related peers. Yet "relatedness" is an encompassing yet elusive concept. To determine how related a firm is to another inevitably depends on the nature of the task at hand and requires considerable judgment. Despite a large volume of literature on the settings where peers are referenced (e.g., Bhojraj and Lee 2002; Foster 1981; Gibbons and Murphy 1990) and the methods to identify the most appropriate peers (e.g., Hoberg and Phillips 2010, 2016; Lee, Ma and Wang 2015), relatively little is known about the factors that influence economic agents' perception about the relatedness between two firms. Insights into this question are important because ultimately, it is the perceived (rather than actual) relatedness that determines the extent to which an agent relies on a particular peer to inform her decision-making. To fill this void, this paper proposes a novel channel through which perceived relatedness can be shaped and altered - the media. Specifically, I examine if and how co-appearance in the same news article affects equity investors' perception about the economic relatedness between the cocovered firms, which is inferred from the efficiency of the information transfer process between them during earnings announcement days.

The financial media is an important information intermediary in capital markets. ${ }^{1}$ To date, the literature has mainly focused on the effects of media coverage of a particular event and suggests that the mere presentation of the event in a popular media outlet can significantly increase the market's reaction to that event due to heightened investor attention. ${ }^{2}$ However, apart from the economic event that forms the central story of the article, journalists often co-cover other relevant firms pertinent to the central story as background information in an effort to provide original editorial analysis to the readers (Call, Emett,

\footnotetext{
${ }^{1}$ For example, Fang and Peress (2009) find that firms with high media coverage have lower cost of equity because of higher transparency. Coverage in the media is also shown to reduce information asymmetry (Tetlock 2010) and facilitate the incorporation of information in stock prices (Peress 2008).

${ }^{2}$ For example, Engelberg and Parsons (2011) exploit a setting in which investors have access to different media coverage of the same information to examine the effects of local newspaper coverage on local investor trading. Peress (2014) shows that investors' trading activities, as measured by trading volume, return dispersion, and volatility, decreased significantly during a newspaper strike.
} 
Maksymov and Sharp 2020). For example, consider the following Wall Street Journal (WSJ) (Adamy 2004) article about Kellogg Co.'s third quarter earnings announcement in 2004:

Kellogg Co. (K) [emphasis added] said earnings grew nearly 7\% in the third quarter, prompting the cereal giant to raise its earnings forecast for the remainder of the year.... Archrival General Mills Inc. (GIS) [emphasis added], maker of Cheerios and other cereals, has been spending heavily to grab a bigger piece of the cereal market. Last month, the Minneapolis company said fiscal firstquarter earnings fell $19 \%$ in part because of higher promotion expenses.... The company also said increased spending on brand building would hurt results during the fourth quarter, joining a group of consumer-products companies including Colgate-Palmolive Co. (CL) and Unilever (UN) [emphasis added] that have said recently higher marketing costs would eat into profits.

In this example, the central story of the article is Kellogg's earnings announcement, but the reporter also co-covered three other firms - General Mills, Colgate-Palmolive, and Unilever — that served as background information to inform readers about Kellogg's competitive position relative to its peers. Therefore, this article not only brought Kellogg's earnings announcement to the readers' attention, but also highlighted the economic relatedness among all the firms that co-appeared in it. ${ }^{3}$

I expect that co-appearance in the same news article could increase investors' perceived relatedness between the co-covered firms because co-coverage can accentuate the firms' relevance to each other. Previous studies suggest that investors tend to overreact to highly salient stories covered by the press even if they do not contain any new information. For example, Huberman and Regev (2001) find that investors react to redundant information published in New York Times that was previously reported in Nature and other news outlets due to the greater publicity generated by the New York Times coverage. Similarly, Tetlock (2011) documents that investors overreact to stale information published by Dow Jones newswire, as the broad reach of the newswire increases the salience of the events. Hillert, Jacobs and Muller (2014) find that firms in the spotlight of media attention tend to have stronger momentum that reverses in the long

\footnotetext{
${ }^{3}$ Appendix A provides more examples of media co-coverage.
} 
term, consistent with coverage in popular press exacerbating investor bias. Thus, to the extent that media co-coverage highlights the relatedness between two firms, investors may overestimate the covariance between the co-covered firms' exposure to common shocks. This bias may affect the efficiency with which investors use one co-covered firm's information when updating their expectation about the performance of another, such as during information transfers, and lead to mispricing in the firms' stock prices. Specifically, if investors over-extrapolate a peer's earnings news to the focal firm due to inflated perceived relatedness caused by media co-coverage, there is likely to be an overreaction to the early-announcing co-covered peer's earnings announcement, which is then corrected when the focal firm announces its own earnings. Therefore, if media co-coverage increases perceived relatedness between the co-covered firms, I hypothesize a negatively relationship between an early-announcing co-covered peer's earnings announcement return and the focal firm's own earnings announcement return, and that this negative relationship should exist only in the period after the publication of the news article where they were cocovered. $^{4}$

Nevertheless, it is also possible that media co-coverage has no effect on the efficiency of information transfers between the co-covered firms, as investors may only focus on the main story of the article and overlook firms mentioned as background information, given limited attention (e.g., Hirshleifer and Teoh, 2003). In addition, as journalists often rely on third-parties' opinion as input to compensate for their lack of financial sophistication (Call et al. 2020), their choice of co-coverage firms may contain little new information about the common shocks that affect the co-covered firms, or the correlation between those firms' exposure to common shocks. Thus, co-coverage may have little impact on investors' perception if their evaluation of relatedness is based solely on economic fundamentals. Furthermore, even if media cocoverage does inflate investors' perceived relatedness between the co-covered firms, it may not be sufficient to prompt them to alter their trading decisions during the firms' earnings announcements, in which case the bias will be too small to be manifested in stock returns. Therefore, it is an empirical question whether media

\footnotetext{
${ }^{4}$ Appendix B provides an algebraic illustration of the negative return predictability in the information transfer process between the co-covered firms.
} 
co-coverage will lead investors to overreact to co-covered peers' earnings announcements in information transfers.

I test my hypothesis on a sample of 1,814 pairs of co-covered firms collected from full articles on companies' earnings announcements published by the WSJ between 2004 and 2016. The sample period is limited by the availability of data necessary to calculate all necessary variables used in the analysis. I focus on the WSJ because it is one of the most authoritative and widely circulated financial newspapers in the United States, making it an ideal setting to investigate the effects of media co-coverage on stock prices. By collecting co-covered firms from earnings-announcement-related articles, I can control for the context in which co-coverage occurs, thereby alleviating the concern that journalists' co-coverage choice for different types of news events may differentially affect its influence on investors' perceived relatedness between the co-covered firms. To isolate the effects of media "co-coverage" (which enhances the salience of the relatedness between two firms) from "coverage" (which enhances the salience of a single firm or event) and to provide a clean setting where inferences can be made, I include in the analysis only firms that are not featured by the WSJ as the main story of the article, and require a firm-pair to be co-covered only once during the window of analysis, which will be detailed in Section $2 .{ }^{5}$

To control for correlated omitted variables that affect both media co-coverage and the efficiency of information transfers, I employ a time-series design that incorporates both the pre- and post-co-coverage periods, and find empirical results consistent with my hypothesis. Specifically, contrary to the general finding of a positive correlation between the peer's and the focal firm's earnings announcement returns (i.e., underreaction) from prior literature (e.g., Ramnath 2002), I document a negative relationship between an early-announcing co-covered peer's announcement return and the focal firm's own announcement return.

\footnotetext{
${ }^{5}$ In the context of the previous example, there are four firms that were co-covered in the article: Kellogg, General Mills, Colgate-Palmolive, and Unilever, from which twelve firm-pairs can be formed. As Kellogg has been covered by the Wall Street Journal as an article's main story (which in this case is about its earnings announcement), all firmpairs involving Kellogg will be excluded from the analysis. Similarly, if General Mills, Colgate-Palmolive, or Unilever has been the central story of a Wall Street Journal article, or if they have co-appeared in other Wall Street Journal articles besides the one about Kellogg's earnings announcement, all firm-pairs involving those firms will be excluded from the analysis.
} 
This negative relationship is present only in the post co-coverage period but not in the pre period before the article is published, lending support to the conjecture that the negative return predictability can be attributed to media co-coverage. ${ }^{6}$ In terms of economic magnitude, a hedging strategy longing (shorting) firms whose co-covered peers' announcement returns are in the lowest (highest) decile yields a significantly positive one-day return of $0.63 \%$ (and a four-factor alpha of $0.62 \%$ ) on the firms' own announcement day. These findings suggest that co-appearance in the same news article can lead investors to exaggerate the relatedness between the co-covered firms, which may result in temporary mispricing in stock prices.

To validate that the observed negative relationship between the co-covered firms' announcement returns is indeed due to media co-coverage causing investors to over-extrapolate co-covered peers' earnings news to the focal firm during information transfers, I perform two sets of cross-sectional tests. In the first set of tests, I examine if the negative return predictability is stronger when investors are more likely to pay attention to the news article where the two firms were co-covered. If investors' perception about the relatedness between the two firms is indeed affected by media co-coverage, the negative relationship between the co-covered firms' announcement returns should be stronger when public attention to the article is higher. I identify two situations where the article is more likely to attract attention. The first is when the earnings announcement that constitutes the central story of the article (e.g., Kellogg's earnings announcement in the previous example) has higher news content, as measured by abnormal intraday volatility (Beaver, McNichols and Wang 2020). If Kellogg's earnings news surprised investors, they will be more likely to search for and read follow-up news articles covering Kellogg's announcement for more in-depth analysis, and therefore will be more likely to pay attention to the co-covered firms mentioned in the article (i.e., General Mills, Colgate-Palmolive, and Unilever). The second situation is when the earnings announcement (e.g., Kellogg's announcement) and the article that covers it as its central story are not both released during daytime hours on the same trading day. When a firm announces its earnings before or during trading hours, investors' attention is likely to be primarily on the firm's own press releases and other direct

\footnotetext{
${ }^{6}$ Figure 1 provides a timeline for the information transfer tests.
} 
communications rather than reports from information intermediaries like the media that reiterate the main points of the press release (e.g., Guest 2019). ${ }^{7}$ Thus, if a news article is not published during (or before) the same trading period on the same trading day as the earnings announcement covered by it, it is likely to receive more attention from investors, and consequently the influence of media co-coverage is likely to be stronger.

In the second set of tests, I investigate if the negative return predictability is stronger when the early-announcing co-covered peer's announcement is more relevant to the focal firm in information transfers. If the co-coverage-induced bias in perceived relatedness indeed leads investors to overweight the peer's earnings news when updating expectations about the focal firm, the negative relationship between the co-covered firms' announcement returns should be stronger when the peer's earnings information is more relevant to the focal firm's upcoming announcement, as relevant peers are more likely to be used in information transfers. I rely on two measures to gauge the relevance of the early-announcing peer's earnings. The first is if the peer and the focal firm's earnings announcements are for the same fiscal quarter, as earnings measured over the same period are more comparable (e.g., Ramnath 2002, Thomas and Zhang 2008). The second is the extent to which the investment community regard the focal firm to be related to the peer as measured by their average Edgar co-search traffic over the past year (Lee, Ma and Wang 2015), since the earnings of a more economically related peer are more likely to be considered relevant in information transfers. All these conjectures are borne out by the data.

In supplementary analysis, I conduct two additional tests to pinpoint the underlying channel through which media co-coverage affects the efficiency of information transfers from the co-covered peer to the focal firm. First, I expect the effects of media co-coverage to be stronger when the focal firm has higher uncertainty, as measured by average analyst earnings forecast dispersion over the past year, since

\footnotetext{
${ }^{7}$ Although previous studies suggest that media coverage does increase investor attention to firms' earnings announcements (e.g., Engelberg and Parsons 2011, Peress 2014), the effects are likely to be smaller for firms whose earnings announcement is covered by the WSJ, as they tend to be large, visible firms whose earnings are closely followed by the market. Thus, it is less likely that investors will attend to the news article first before they go through the announcing firm's disclosures.
} 
prior research documents that investors are more prone to behavioral biases when they trade the stocks of hard-to-value firms (e.g., Daniel, Hirshleifer and Subrahmanyam 1998, 2001). Second, I expect the effects of media co-coverage to be stronger for retail investors, as they are more likely to rely on the media as the main source of information than institutional investors due to limited attention (e.g., Barber and Odean 2008, Tetlock 2011, Solomon, Soltes and Sosyura 2014). I use the change in abnormal retail trading volume of the focal firm on the peer's earnings announcement day in the post-co-coverage period relative to the pre period to measure the change in retail attention to the focal firm when the peer announces earnings (Boehmer, Jones, Zhang and Zhang 2019). A more positive change in abnormal retail trading volume implies higher retail attention to the focal firm on the peer's announcement day after media co-coverage, which implies higher perceived relatedness between the focal firm and the peer by retail investors. Empirical results suggest that the negative return predictability is stronger when the focal firm has higher analyst forecast dispersion, and when the change in retail trading of the focal firm's stock on the peer's earnings announcement day in the post period is more positive. Taken together, findings in this paper suggest that media co-coverage can significantly affect investors' perception about the relatedness between the co-covered firms, which may lead to suboptimal investment decisions.

This paper adds to several streams of literature. First, it adds to the literature on the identification of economically related peers. Recent studies have developed several innovative methods to identify the most appropriate peers that market participants should use in their decision making, such as textual analysis of firms' 10-K filings (Hoberg and Phillips 2010, 2016), analyst co-coverage (Ramnath 2002), and Edgar co-search traffic (Lee, Ma and Wang 2015). However, what determines economic agents' perception about the relatedness between two firms remains an open question, and more research is needed beyond simple characteristics-based explanations such as industry (e.g., Chan, Lakonishok and Swaminathan 2007), stock index membership (e.g., Barberis, Shleifer and Wurgler 2005; Greenwood 2007; Boyer 2011), and stock price (e.g., Green and Hwang 2009). After all, it is perceived, not actual, relatedness that determines the extent to which a peer will be used as a reference point. By introducing the concept of media co-coverage, this paper provides new insights into the factors that affect market participants' perceived relatedness 
between firms, and suggests that distorted perception about firms' economic relatedness can result in inefficient trading decisions by stock investors.

Second, it contributes to the literature on the role of media in financial markets by examining the stock market consequence of journalists' co-coverage choices. Previous studies have mainly focused on the media's coverage of individual firms or news events (e.g., Huberman and Regev 2001, Fang and Peress 2009, Engelberg and Parsons 2011), while in practice journalists often co-cover other related firms beyond those directly involved in the central story as supplementary information. Despite the prevalence of cocoverage, the potential capital market consequences of this practice have been underexplored in current literature. To fill this gap, this paper examines one possible effect of media co-coverage-increased salience of the relatedness between the co-covered firms - and its influence on the efficiency of the information transfer process between them during earnings announcements.

Third, this paper contributes to the literature on the efficiency of stock market reaction to publicly available information. Ample evidence exists in prior research that investors tend to underreact to public news, including a firm's own past earnings (e.g., Bernard and Thomas 1990), industry peers' earnings (e.g., Ramnath 2002, Thomas and Zhang 2008) ${ }^{8}$, and other information events (e.g., Loughran and Ritter 1995, Ikenberry, Lakonishok and Vermaelen 1995, Ikenberry, Rankine, and Stice 1996). This paper suggests that when the relevance of a piece of public information is made salient to investors by the media, investors actually overreact to that information due to heightened attention. To the best of my knowledge, this study is the first to investigate the effects of media co-coverage on the stock market, and its findings can shed light on a potentially unintended consequence of this common practice in news reporting on the investment decisions of stock investors.

\footnotetext{
${ }^{8}$ The negative relationship between the co-covered firms' announcement returns documented in this study is different from the return reversal anomaly in Thomas and Zhang (2008), which find a negative relationship between the focal firm's excess return on an early-announcing industry peer' announcement day and the focal firm's own announcement return. It is worth noting that in their study, the relationship between the peer' announcement return and the focal firms' announcement return is also significantly positive, which is consistent with the findings in Ramnath (2002).
} 


\section{Sample and Research Design}

\subsection{Construction of the Media Co-coverage Database}

The steps to construct the media co-coverage database are summarized in Table 1. First, I collect full articles published by the WSJ about companies' earnings announcements from 2004 to 2016 using the RavenPack database, which pre-classifies news stories into more than 2,000 event categories using a proprietary algorithm. Although RavenPack started news coverage in 2000, its event classification algorithm has improved significantly since 2003. Thus, I start my sample period in 2004. This step results in 5,984 articles mentioning 17,265 firms in total. Matching a firm to all other firms mentioned in the same article yields 51,694 firm-pairs, which forms the initial co-coverage database. Firm-pair $i-j$ indicates that firm $i$ is the focal firm, and $j$ is the co-covered peer.

Second, if a firm-pair is co-covered in multiple articles during the same day (such as when there are multiple versions of the same article with minor revisions), the earliest article is kept. Third, I drop firms that are likely to play a "source" role in the article, such as investment banks, publishing companies (e.g., Thomson Reuters), and research firms (e.g., FactSet Research Systems). Fourth, I drop firm-pairs where the two firms belong to the same business group to make the examination of information transfers meaningful. Specifically, I eliminate a firm-pair if at least $80 \%$ of the company names are the same. Fifth, I drop firm-pairs where at least one of the firms is a non-US firm, as investors do not pay the same level of attention to domestic stocks as they do to international stocks (e.g., French and Poterba 1991). After these steps, the sample is reduced to 1,739 articles, 4,813 firms and 10,374 firm-pairs.

Sixth, for each firm-pair $i$ (focal firm) $-j$ (co-covered peer), I identify peer $j$ 's first earnings announcement following the article publication day $\left(A N N D A T S_{-} P\right)$, and focal firm $i$ 's first earnings announcement following $j$ 's earnings announcement (ANNDATS). To be included in the sample, the firms are required to have non-missing earnings announcement date and timestamp in $\mathrm{I} / \mathrm{B} / \mathrm{E} / \mathrm{S}$ to adjust for overnight announcement. This step reduces the sample to 1,461 articles, 3,840 firms and 7,530 firm-pairs.

Seventh, I drop firm-pairs where the article publication day and the two firm's earnings announcement days are too far apart to exclude irregular announcements. Specifically, a firm-pair is 
excluded from the analysis if (a) the fiscal quarter ends of the focal firm and the co-covered peer are more than 3 months apart; or (b) the number of days between the article publication day and the peer's earnings announcement is more than 100 days; or (c) the number of days between the article publication day and the focal firm's earnings announcement is more than 200 days. After this step, the sample includes 1,441 articles with 3,708 firms and 7,199 firm-pairs.

Eighth, to alleviate the concern that the effects of co-coverage may be contaminated by media coverage, I drop firm-pairs where at least one of the firms was featured as the central story of a WSJ article for any type of economic events (including but not limited to earnings announcements) over the window of analysis, which is defined as $[t-100, A N N D A T S]$, where $t$ is the article publication day. The requirement that a firm should have no coverage by the WSJ over a 100-day period prior to the article publication day is to prevent any lingering effects of media coverage on investor attention to the firm. Similarly, the requirement that a firm should have no WSJ coverage between the article publication day (i.e., the date of co-coverage) and the focal firm's earnings announcement (ANNDATS) is to ensure that the effects of cocoverage will not be contaminated by other instances of media coverage over the information transfer period. This step also ensures that any observed effects are not due to the two firms being involved in the same economic event (e.g., mergers and acquisitions). After this step, the sample is reduced to 688 articles, 1,612 firms and 2,673 firm-pairs.

Nineth, to further ensure that any observed effects can be cleanly attributed to the two firms being co-covered on the article publication day $t$, I drop firm-pairs where the two have co-appeared in the same WSJ article multiple times over [ $t-100, A N N D A T S]$, where $t$ is the article publication day. In other words, this step ensures that the day $t$ co-coverage is the only instance of co-coverage between firm $i$ and $j$ over the window of analysis. This step reduces the sample to 684 articles, 1,605 firms and 2,656 firm-pairs.

Tenth, I drop firm-pairs that are co-covered in articles where the announcing firm whose earnings announcement is the central story of the article cannot be identified in the databases required to calculate announcement-reaction variables (e.g., I/B/E/S and CRSP), or if the announcing firm is not a US firm to 
ensure that variations in investors' attention to the article is not driven by the announcing firm's country of origin. ${ }^{9}$ This step reduces the sample to 472 articles, 1,120 firms and 1,908 firm-pairs.

In the eleventh step, I construct a control sample by identifying the focal firm and the co-covered peer's earnings announcements before the article publication day to address the concern that the media may tend to co-cover firms that investors are more inclined to overreact to in information transfers. Specifically, for each firm-pair $i-j$, I first identify focal firm $i$ 's most recent earnings announcement before the article publication day. I then identify co-covered peer $j$ 's most recent earnings announcement prior to $i$ 's announcement. Again, the fiscal quarter ends of the focal firm and the peer's earnings announcements are required to be no more than 3 months apart. In addition, the number of days between the focal firm's announcement and the article publication day is required to be fewer than 100 days, and the number of days between the peer's announcement and the article publication day is required to be fewer than 200 days. I then match each firm-pair in the post-co-coverage sample (the one from the tenth step) to the corresponding pre-co-coverage observation, and a firm-pair is required to be present in both the post and the pre sample to be included in the analysis to alleviate the concern of survivorship bias. This step reduces the sample to 455 articles, 1,063 firms and 1,814 firm-pairs. Thus, the final sample includes 3,628 observations in total (1,814 from the post/treatment sample, and 1,814 from the pre/control sample).

\subsection{Sample Descriptive Statistics}

Table 2 provides descriptive statistics for the sample. Panel A presents statistics on the characteristics of the co-covered firms included in the post-co-coverage sample, while Panel B compares those firms to their Fama-French 48 (FF48) industry peers (Fama and French 1997). The average market capitalization of the co-covered firms is $\$ 76,428$ million, which is significantly larger than the average market capitalization of the FF48 peers ( $\$ 3,620$ million). The average book-to-market ratio of the cocovered firms is 0.32 , while the average book-to-market of the FF48 peers is 2.36 , suggesting that cocovered firms tend to be growth firms. The average institutional ownership of the co-covered firms is 746.02 ,

\footnotetext{
${ }^{9}$ For example, if General Mills, Colgate-Palmolive, and Unilever were co-covered in an article about a foreign food maker's earnings announcement, these firms will be excluded from the analysis.
} 
which is significantly higher than the average institutional ownership of 123.63 of the FF48 peers. Lastly, both the co-covered firms and the FF48 peers have an average total accruals of -0.01 and the difference is not statistically significant. Overall, the statistics in Panel A and B suggest that the firms that are co-covered in $W S J$ news articles are large firms with high stock market valuation and high institutional ownership.

Panel C provides statistics on the co-covered firms' earnings announcements in both the pre- and post-co-coverage period. The average earnings surprise (multiplied by 100 for presentation purpose) in the post (pre) period is $0.09(0.12)$ with a standard deviation of $0.64(0.56)$. The average market-adjusted return of the focal firm on its own earnings announcement day $\left(E X R E T \_O W N\right)$ is $-0.02 \%(-0.48 \%)$ with a standard deviation of $6.41 \%(5.74 \%)$ in the post (pre) period. Similarly, the average market-adjusted return of the co-covered peer on its own earnings announcement day $($ EXRET_P) is $0.03 \%(-0.16 \%)$ with a standard deviation of $6.39 \%(6.20 \%)$ in the post (pre) period. Lastly, the average market-adjusted return of the focal firm on the peer's earnings announcement day $(E X R E T)$ is $-0.04 \%(0.06 \%)$ with a standard deviation of $2.26 \%(2.36 \%)$ in the post (pre) period. These statistics are consistent with the sample characteristics reported in prior research (e.g., Ramnath 2002, Thomas and Zhang 2008).

\subsection{Research Design}

To control for endogeneity in both media co-coverage and the efficiency of information transfers, I adopt a time-series design to examine the relationship between the co-covered firms' announcement returns in both the pre- and the post-co-coverage period. Specifically, I estimate the following regression:

$$
\begin{aligned}
& \text { EXRET_OWN } N_{i}=\beta_{0}+\beta_{1} * \text { EXRET_P } P_{j} * A F T E R+\beta_{2} * E X R E T_{-} P_{j} * B E F O R E+\beta_{3} * E X R E T_{i, j} * \\
& A F T E R+\beta_{4} * E_{\text {XRET }} * \text { BEFORE }+\beta_{5} * A F T E R+\beta_{6} * S U R P_{i}+\beta_{7} * L O G_{-} M K T C A P_{i}+\beta_{8} * A C C_{i}+\beta_{9} * \\
& B M_{i}+\beta_{10} * \text { PREEXRET }_{i}+\beta_{11} * \text { MOMENTUM } M_{i}+\text { Industry fixed effects }+ \text { Year fixed effects }+\varepsilon_{i},
\end{aligned}
$$

where EXRET_OWN $i$ is the market-adjusted excess return of the focal firm $i$ on its own earnings announcement day. ${ }^{10}$ EXRET_P $P_{j}$ is the market-adjusted excess return of the co-covered peer $j$ on its own earnings announcement day. AFTER (BEFORE) is an indicator variable that is equal to $1(0)$ if an

\footnotetext{
${ }^{10}$ For presentation purpose, all time subscripts are omitted in the regressions unless otherwise noted.
} 
observation comes from the post-co-coverage sample, and 0 (1) if it comes from the pre-co-coverage sample. If media co-coverage increases investors' perceived relatedness between firm $i$ and $j$, which leads them to overreact to $j$ 's earnings announcements, $\beta_{1}$ should be significantly negative while $\beta_{2}$ should be either statistically insignificant or significantly positive.

I include the following variables as controls. $E X R E T_{i, j}$ is the market-adjusted excess return of the focal firm $i$ on peer $j$ 's earnings announcement day and to control for the return reversal anomaly in Thomas and Zhang (2008). SURP is focal firm i's earnings surprise, calculated as the difference between actual earnings and mean analyst forecast, scaled by lagged market capitalization. $L O G_{-} M K T C A P_{i}$ is the natural logarithm of firm $i$ 's market capitalization as of the end of the previous fiscal quarter. $A C C_{i}$ is the total accruals of firm $i$ as of the end of the previous fiscal quarter. $B M_{i}$ is the book-to-market ratio of firm $i$ as of the end of the previous fiscal quarter. PREEXRET is the cumulated market-adjusted excess return of firm $i$ over a three-day window ending two days before $i$ 's earnings announcement day to control for the liquiditydriven reversal in So and Wang (2014). MOMENTUM $M_{i}$ is the cumulative market-adjusted excess return of firm $i$ over a ninety-day window ending five days before $i$ 's earnings announcement to control for return momentum (e.g., Hong and Stein 1999). I include industry (based on Fama-French 48 industries) and year fixed effects in regression (1) to control for any industry- or time-specific factors that affect announcement returns. Standard errors are double-clustered by firm and quarter following Petersen (2009).

\section{Univariate Analysis}

Before discussing the estimation results of regression (1), I first conduct a univariate analysis and report the correlation statistics between the co-covered peer and the focal firm's announcement returns in both the post- and the pre- period in Panel A of Table 3. On the left-hand side of the panel where the correlations are calculated using the post-co-coverage sample, EXRET_P and EXRET_OWN has a Pearson correlation of -0.05 , significant at the $5 \%$ level. On the right-hand side where the correlations are calculated using the pre-co-coverage sample, EXRET_P and EXRET_OWN has a Pearson correlation of 0.04, which is statistically insignificant. In both the post and the pre period, there is a significantly positive correlation 
between EXRET_P and EXRET, which is consistent with the findings from prior research that information transfers are on average positive (e.g., Kim, Lacina, and Park 2008; Wang 2014). The correlation between EXRET and EXRET_OWN is statistically insignificant, which suggests that the focal firm's excess returns on the co-covered peer's announcement day and its own announcement day are largely uncorrelated. ${ }^{11}$ These results suggest that the negative relationship between the co-covered firms' announcement returns is observed only in the post-co-coverage period, which is consistent with the main hypothesis that media cocoverage leads investors to overreact to co-covered peer's earnings announcement in information transfers.

To gauge the economic magnitude of the overreaction, I develop a daily long-short strategy whereby I long (short) focal firms whose co-covered peers have lower (higher) earnings announcement returns. Specifically, I sort co-covered peers into deciles by their announcement return EXRET_P. Due to limited number of observations, the sorting is based on the distribution of EXRET_P over the whole sample. ${ }^{12}$ I then long (short) focal firms whose co-covered peers are in the lowest (highest) decile (equalweighted) at the beginning of the focal firm's earnings announcement day and close the position at the day's end. A positive hedge return would imply that focal firm investors overreact to the co-covered peers' earnings news.

In Panel B of Table 3, I present the estimation results from this long-short strategy. During the postco-coverage period, the average EXRET_P in the lowest (highest) decile is $-12.51 \%(11.02 \%)$. The average EXRET_OWN of the focal firms whose co-covered peers' EXRET_P are in the lowest (highest) decile is $0.69 \%(0.06 \%)$. On the focal firms' announcement days, a hedge portfolio that takes a long (short) position in those whose peers are in the low (high) EXRET_P decile yields a one-day return of $0.63 \%$, significant at the $10 \%$ level. During the pre-co-coverage period, the average EXRET_P in the lowest (highest) decile is -

\footnotetext{
${ }^{11}$ Ramnath (2002) documented a positive relationship between the focal firm's return on peers' announcement days and the focal firm's own announcement day, while Thomas and Zhang (2008) found the relationship to be negative. In this paper, I do not seek to reconcile these findings as the differences are likely to be a result of different sample construction procedures and research design.

${ }^{12}$ The purpose of this analysis is not to create a trading strategy that maximizes the alpha that investors can realize, but to show that the increased perceived relatedness caused by media co-coverage can result in statistically significant and economically meaningful mispricing in the information transfer process between the co-covered firms.
} 
$12.42 \%(10.57 \%)$. The average EXRET_OWN of the focal firms whose co-covered peers' EXRET_P are in the lowest (highest) decile is $-0.38 \%(-0.02 \%)$. The return from the hedge portfolio is $-0.37 \%$ and is statistically insignificant. These findings corroborate the evidence in Panel A.

I next investigate whether the trading strategy can generate positive abnormal returns as measured by alpha. Specifically, I regress the hedge returns from the post-co-coverage sample on the market, size, book-to-market and momentum factors (Carhart 1997) and present the results in Panel C of Table $3 .{ }^{13}$ The intercept of the estimated regression is 0.62 and is significant at the $5 \%$ level, indicating that implementing this strategy can generate a positive daily alpha of $0.62 \%$. Taken together, findings in Table 3 suggest that media co-coverage can have a significant effect on the efficiency of the information transfer process between the co-covered firms.

\section{Main Analysis}

\subsection{Media Co-coverage and the Efficiency of Information Transfers}

Table 4 presents the estimation results of regression (1). In Column (1) where there are no fixed effects, consistent with findings in the univariate analysis, the coefficient on the interaction variable EXRET_P * AFTER is -0.05 and is significant at the $10 \%$ level, while the coefficient on EXRET_P * BEFORE is statistically insignificant. The coefficients on the interaction variables $E X R E T * A F T E R$ and EXRET * BEFORE are both insignificant. In Column (2) where industry and year fixed effects are added, the coefficient on EXRET_P*AFTER is -0.05 and is significant at the 5\% level, while the coefficient on EXRET_P * BEFORE remains insignificant. Thus, evidence in Table 4 lends further support to the hypothesis that focal firm investors overreact to a peer's earnings news when the two firms have been cocovered in the same news article.

\footnotetext{
${ }^{13}$ The factors are obtained from Kenneth French's website: https://mba.tuck.dartmouth.edu/pages/faculty/ken.french/data_library.html.
} 


\subsection{Effects of Media Co-coverage and Public Attention to the Article}

To provide further validation that the negative relationship between $E X R E T \_P$ and $E X R E T \_O W N$ documented in Table 4 and Table 5 can indeed be attributed to media co-coverage increasing the perceived relatedness between the co-covered firms, I conduct two cross-sectional tests. In this sub-section, I investigate if the negative return correlation is stronger when the article where the two firms are co-covered receives more public attention. When investors pay more attention to the article, they are more likely to be subject to the co-coverage effect, and therefore are more likely to over-extrapolate one co-covered firm's earnings news to another.

I identify two situations where investors are more likely to pay attention to the article. The first is when the article covers an earnings announcement that has high information content, in which case investors are more likely to be interested in reading the media's coverage on it for more details and analysis. I measure the information content of an earnings announcement using abnormal intraday volatility following Beaver, McNichols and Wang (2020). First, I identify the announcing firm whose earnings announcement is the central story of the article (e.g., Kellogg). Second, I calculate the announcing firm's market-adjusted return by regressing its daily stock return on the value-weighted CRSP index return over a 365-day period ending 10 days prior to its earnings announcement (i.e. the earnings announcement covered by the $W S J$ article as the main story). I then take the residuals and calculate their variance over this benchmark period VAR_RETANN_BENCH. Third, I use the coefficients from the market regression to calculate the market-adjusted return of the announcing firm on its earnings announcement day and take its square SQRRETANN_RES. The abnormal return volatility (USTAT_RAW) of the announcing firm on its earnings announcement day is calculated as SQRRETANN_RES divided by VAR_RETANN_BENCH. As prior research shows that return volatility on firms' earnings announcement days depends on the amount of time investors have to process the information (e.g., Lyle, Rigby, Stephan and Yohn, 2020) and has been increasing in recent years (Beaver, McNichols and Wang 2020), I calculate a residual abnormal return volatility measure to reduce the noise introduced by these two factors in the raw measure USTAT_RAW. Specifically, I regress USTAT_RAW on the natural logarithm of one plus the number of days between the 
earliest trading day when investors can trade the announcing firm's stocks and the date of the announcement to control for the timing of the earnings announcement, and year-quarter fixed effects to control for the time trend. The residual from this regression USTAT is used to measure the news content of the announcing firm's earnings announcement. An article is regarded as receiving high investor attention $(A T T=1)$ if the USTAT of the earnings announcement it covers as central story is above the sample median. Otherwise, it is regarded as receiving low attention $(A T T=0)$.

The second situation when investors are more likely to pay attention to the article is when the news article and the earnings announcement that it covers as the main story are not published during the daytime period on the same trading day, as investors are likely to focus primarily on the announcing firm's disclosures rather than the media's paraphrasing if both are released during (or before) trading hours. Therefore, an article is likely to receive high attention $(A T T=1)$ when the article itself and the earnings announcement covered by it are not released on the same trading day before market closes. Otherwise, the article is regarded as having low attention $(A T T=0)$.

To test if the negative relationship between EXRET_P and EXRET_OWN in the post-co-coverage period is stronger when the article receives more investor attention, I modify regression (1) by further interacting EXRET_P * AFTER with ATT. To address the concern that some correlated omitted variables may be responsible for both the efficiency of the information transfer process and the propensity of the two firms to be co-covered in a high-attention article, I also interact EXRET_P*BEFORE with ATT. The control variables remain the same as in regression (1).

The estimation results are tabulated in Table 5. In Column (1) and (2), ATT is based on abnormal return volatility of the announcing firm. The coefficient on EXRET_P*AFTER is statistically insignificant, while the coefficient on EXRET_P*AFTER * ATT is significantly negative, both with and without fixed effects. This suggests that focal firm investors overreact to the co-covered peer's earnings news only when they are more likely to pay attention to the article where the two are co-covered. The coefficient on EXRET_P * BEFORE is significantly positive, while the coefficient on EXRET_P * BEFORE * ATT is insignificant in Column (1) and significantly negative in Column (2). Thus, there is evidence that focal firm 
investors underreact to the co-covered peer's earnings announcement in the pre-co-coverage period, though the magnitude of the underreaction seems to be smaller for firms co-covered in articles about highinformativeness earnings announcements. ${ }^{14}$ Similarly, in Column (3) and (4) where ATT is based on timing of the article and the earnings announcement it covers, the coefficient on EXRET_P*AFTER is statistically insignificant and the coefficient on EXRET_P *AFTER * ATT is significantly negative. The coefficients on EXRET_P * BEFORE and EXRET_P* BEFORE * ATT are both statistically insignificant, suggesting that there is no detectable inefficiency in focal firm investors' reaction to the peer's announcement in the pre-co-coverage period. Overall, evidence in Table 5 is consistent with the conjecture that focal firm investors are less likely to over-extrapolate a co-covered peer's earnings when they pay less attention to the article that co-mention the two firms.

\subsection{Effects of Media Co-coverage and Relevance of Peer Earnings in Information Transfers}

In this sub-section, I examine if the negative return predictability is stronger when the co-covered

peer's earnings announcement is more relevant to the focal firm's upcoming earnings announcement in information transfers. The more relevant the peer's earnings news, the more likely that investors will use it to update their expectations about the focal firm's earnings, and the more likely that the effects of media co-coverage will manifest in their reaction to the peer's earnings announcement.

I rely on two measures to assess the relevance of a co-covered peer's earnings to the focal firm. The first is if the peer and the focal firm's earnings are measured over the same fiscal quarter, since the early-announcing peer's earnings news will be more relevant to the focal firm's upcoming announcement if the two firms' earnings are measured over the same time period $(R L V=1)$ than when there is little overlap between the measurement windows of the two firms' earnings $(R L V=0)$.

\footnotetext{
${ }^{14}$ One possible explanation is that firms' earnings announcement informativeness may contain an industry component and is sticky over time. Thus, firms related to the announcing firm whose high-news-content earnings announcement is covered by the WSJ may also tend to have relatively high news content in their own earnings announcement. Since firms co-covered in the WSJ article as background information are likely to be economically related to the announcing firm, their earnings announcements may have higher informativeness as well. As in general, investors pay more attention to firms whose earnings announcements have high news content (e.g., Koester, Lundholm and Soliman 2016), the firms co-covered in articles about high-informativeness earnings announcements may on average receive more attention. Thus, there might be less underreaction between such firms in information transfers.
} 
The second measure is the level of economic relatedness between the focal firm and the co-covered peer, as the earnings of a more related peer is more likely to be relevant in information transfers. I use the Edgar co-search traffic measure developed in Lee, Ma and Wang (2015) to gauge the degree of economic relatedness between the two firms, as it directly captures the investment community's average perception about their relatedness. Specifically, for each firm pair $i-j$, I measure their co-search traffic as the number of daily searches for focal firm $i$ after co-covered peer $j$ over a 365-day period ending 10 days before the peer's earnings announcement, scaled by the number of daily searches for any firm after co-covered peer $j$ over the same period. This measure captures the extent to which Edgar users consider $i$ to be relevant to $j$ over the one-year window prior to $j$ 's announcement. As there are systematic differences in Edgar search traffic across industries, I sort firm-pairs by their co-search traffic within the co-covered peer's FF48 industry, and peer $j$ 's earnings announcement is considered to be relevant to focal firm $i(R L V=1)$ if their co-search traffic is above the industry median. Otherwise, $j$ 's announcement is regarded as less relevant $(R L V=0)$.

To test if the negative return predictability in the post-co-coverage period is stronger when the cocovered peer's announcement is more relevant in information transfers, I interact EXRET_P*AFTER and EXRET_P* BEFORE in regression (1) with $R L V$ and present the estimation results in Table 6. In Column (1) and (2) where $R L V$ is based on the two firms' fiscal quarter ends, the coefficient on EXRET_P*AFTER * $R L V$ is significantly negative, while the coefficient on EXRET_P*AFTER is statistically insignificant. This suggests that the over-extrapolation of a co-covered peer's earnings news in the post period exists only when the two firms are reporting earnings for the same quarter. The coefficients on EXRET_P* BEFORE * RLV and EXRET_P* BEFORE are both statistically insignificant, suggesting that overreaction to peer earnings is not present in the pre-co-coverage period even if the two firms reported earnings for the same quarter, which lends further support to the conjecture that the overreaction can be attributed to media cocoverage.

In Column (3) and (4) where RLV is based on the two firms' Edgar co-search traffic, the coefficient on EXRET_P *AFTER * RLV is significantly negative and the coefficient on EXRET_P * AFTER is 
statistically insignificant, suggesting that the overreaction is only present when the focal firm is considered relevant to the early-announcing peer. The coefficient on EXRET_P * BEFORE is significantly positive, which indicates that focal firm investors actually underreact to the peer's earnings before they are cocovered by the media. Taken together, the results in Table 6 are consistent with the hypothesis that the effects of media co-coverage on the efficiency of information transfers are stronger when investors are more likely to use the co-covered peer's earnings announcement to infer the upcoming earnings announcement of the focal firm.

\section{Supplementary Analysis}

\subsection{Additional Factors that Affect the Effects of Media Co-coverage}

To provide further evidence on the mechanisms through which media co-coverage affects focal firm investors' reaction to a co-covered peer's earnings announcement, I conduct two additional tests. First, I examine if the effects of co-coverage are stronger when the focal firm has higher uncertainty. The higher the uncertainty, the more subjective judgment it requires to infer the focal firm's earnings from the earlyannouncing peers, and the more likely that investors will be prone to the behavioral bias induced by media co-coverage (e.g., Daniel, Hirshleifer and Subrahmanyam 1998, 2001). I measure firm uncertainty using the average analyst earnings forecast dispersion for the focal firm's quarterly earnings announced over a 365-day benchmark window ending one day before the co-covered peer's earnings announcement day, and sort firm-pairs by the focal firm's average analyst forecast dispersion within its FF48 industry. A focal firm is regarded as having high uncertainty $(U N C=1)$ if its average analyst forecast dispersion is above the industry median, provided that there are on average more than 5 analysts providing forecasts over the benchmark window. Otherwise, it is considered as having low uncertainty $(U N C=0)$.

Second, I investigate if the negative relationship between the co-covered firms' announcement returns can be mainly attributed to retail investors. In general, the extant literature argues that media coverage exerts a stronger effect on retail investors' trading activities than institutional investors because they are more likely to rely on the media as their main information source due to limited attention (e.g., 
Barber and Odean 2008). ${ }^{15}$ I use the change in the abnormal retail trading volume of the focal firm on the co-covered peer's earnings announcement day in the post-co-coverage period over the pre-co-coverage period to measure the extent to which retail investors' perceived relatedness between the two firms changes due to media co-coverage. A more positive change indicates higher perceived relatedness in the post period. Abnormal retail trading volume is calculated as the ratio of retail dollar volume of the focal firm $i$ on the co-covered peer's earnings announcement day ANNDATS_P to the average retail dollar volume of $i$ over a 365-day benchmark window ending 10 days prior to day ANNDATS_P. To measure retail dollar volume, I follow the procedures of Boehmer, Jones, Zhang and Zhang (2019). Specifically, for all trades with exchange code " $\mathrm{D}$ " in the TAQ database, if the fraction of a penny associated with the transaction price of a particular trade is between 0 and 0.4 (between 0.6 to 1), the transaction is coded as retail seller-initiated (retail buyer-initiated). Transactions at a round penny or near the half-penny are not coded to ensure data accuracy. I then scale the raw retail dollar volume by total dollar volume when calculating the abnormal retail trading volume measure. Next, for each firm-pair $i-j$, I calculate the change in focal firm $i$ 's abnormal retail trading volume on peer $j$ 's earnings announcement day in the post period over that in the pre period, and sort firm-pairs by focal firm $i$ 's change in abnormal retail trading volume within its FF48 industry. A focal firm is considered to have abnormally high retail activity on the peer's announcement day in the post period $(R E T A I L=1)$ if the change in its abnormal retail trading volume is above the industry median, provided that there is non-zero retail trading over the benchmark window. Otherwise, the focal firm is regarded as having low retail activity $(R E T A I L=0)$.

To test if overreaction to a co-covered peer's earnings in the post-co-coverage period is stronger when the focal firm has higher uncertainty, I interact EXRET_P $*$ AFTER and EXRET_P * BEFORE in

\footnotetext{
${ }^{15}$ For example, Tetlock (2011) show that market reaction to stale information published by the media is mainly driven by individual investors rather than institutional investors. Similarly, Solomon, Soltes, and Sosyura (2014) document that retail investors are more likely to allocate money to a mutual fund if the fund has been recently featured in the media. However, empirical evidence on whether retail investors are more prone to the media's influence is not entirely conclusive. For example, Kaniel and Parham (2017) find increased capital inflows to mutual funds featured in the Wall Street Journal's "Category Kings" ranking list compared with the funds that just missed making the list, but the level of increase did not differ between retail- and institutional-targeted fund classes. Thus, it remains an empirical question whether the media has a stronger effect on retail investors' trading activities.
} 
regression (1) with $U N C$. To test if the overreaction is higher when retail investors perceive the two firms to be more related in the post period, I interact EXRET_P*AFTER with RETAIL. To ensure that any observed effects in the post period are not due to intrinsic characteristics of the focal firm that affect both the change in abnormal retail trading volume and the reaction to the co-covered peer's earnings announcement, I also interact EXRET_P*BEFORE with RETAIL. The estimation results are presented in Table 7. In Column (1) and (2) where UNC is the conditioning variable, the coefficient on EXRET_P* AFTER * UNC is significantly negative, while the coefficient on EXRET_P*AFTER is insignificant. This indicates that high uncertainty focal firms overreact to a co-covered peer's announcement, but not low uncertainty ones. The coefficients on EXRET_P * BEFORE *UNC is significantly positive, while the coefficient on EXRET_P*BEFORE is statistically insignificant. This suggests that before the two firms are co-covered by the WSJ, the focal firm actually underreacts to the peer's earnings if it has higher uncertainty, which is consistent with prior research documenting greater underreaction to public news when uncertainty is higher (e.g., Zhang 2006). The finding that high uncertainty firms underreact to peers' earnings in the pre period while overreact in the post period suggests that investors are more likely to rely on the media as an information source when evaluating firms that are difficult to value, and hence are more subject to the influence of co-coverage.

In Column (3) and (4) where RETAIL is the conditioning variable, the coefficient on EXRET_P* AFTER * RETAIL is significantly negative and the coefficient on EXRET_P * AFTER is statistically insignificant, suggesting that overreaction to a co-covered peer's earnings is stronger when retail investors trade the focal firm's stock more intensively on the peer's announcement day in the post-co-coverage period than in the pre period. The coefficients on EXRET_P*BEFORE $*$ RETAIL and EXRET_P*BEFORE are both insignificant, suggesting that the negative relationship between the two firms' announcement returns in the post period is unlikely to be driven by correlated omitted variables. Overall, evidence in Table 7 indicates that the effects of media co-coverage are more likely to interfere with the information transfer process when the focal firm has higher uncertainty, and that retail investors are primarily responsible for the documented overreaction. 


\subsection{Alternative Explanations}

\subsubsection{The salience of co-covered peers}

One alternative explanation to the negative relationship between two co-covered firms' announcement returns is that the focal firm overreact to the peer's earnings news not because of co-coverage, but because the peer appeared in a WSJ article, which may increase its salience (even if the article is not about the peer's earnings announcement). In other words, the overreaction is due to investors overreacting to the earnings announcement of a salient peer, rather than the two firms co-appearing in the same article. To rule out this explanation, I conduct a placebo test where I identify a placebo firm to replace the focal firm in the main analysis, and examine if investors of the placebo firm overreact to the earnings announcement of the peer. Specifically, for each firm-pair $i-j$ in the main sample, I match the focal firm $i$ to a placebo firm $i$ ' that satisfies one of the following three criteria: (1) $i$ ' is the most similar firm to $i$ based on the Hoberg and Phillips $(2010,2016)$ product similarity measure (HPSIM); or (2) $i$ ' is the most similar firm to $i$ based on HPSIM, given that $i$ ' and $i$ are in the same market capitalization decile as of the end of month $m-1$, where $m$ is the month when the article is published; or (3) $i$ ' is the most similar firm to $i$ based on HPSIM, given that $i$, and $i$ are in the same WSJ coverage decile, with WSJ coverage measured as the number of times a firm is mentioned in a full WSJ article over the quarter $q-1$, where $q$ is the quarter when the article is published. I further require the placebo firm $i$ ' and peer $j$ 's earnings announcements are for the same quarter, as information transfers are the strongest in this case. ${ }^{16}$ All other sample construction procedures are the same as those described in Table 1. I then estimate regression (1) using the sample consisting of firm-pairs $i^{\prime}-j$.

The estimation results are tabulated in Panel A of Table 8. In Column (1) and (2) where the placebo firm $i$ ' is the most similar firm to focal firm $i$, the coefficients on both EXRET_P *AFTER and EXRET_P * BEFORE are statistically insignificant. Similar results can be observed in Column (3) and (4) where the placebo firm $i$ ' is the most similar firm in the same size decile as focal firm $i$, and in Column (5) and (6)

\footnotetext{
${ }^{16}$ Untabulated results suggest that inferences are similar if I do not impose this requirement.
} 
where the placebo firm is the most similar firm in the same WSJ coverage decile as the focal firm. These results suggest that a placebo firm comparable to the focal firm $i$ in terms of product/service portfolios and visibility (as measured by size and $W S J$ coverage) does not overreact to peer $j$ 's earnings announcement in both the pre- and post-co-coverage period. Thus, it is unlikely that the overreaction documented in the main analysis is due to investors overreacting to the earnings of salient firms mentioned in WSJ articles.

\subsubsection{Heightened attention to related firms}

Another alternative explanation for the negative return predictability is that the WSJ coverage of a firm's earnings announcement (e.g., Kellogg's 2004 Q3 earnings announcement) increases investor attention to the earnings announcements of its related firms in general, even if they are not mentioned in the article. In the context of the previous example, this explanation implies that regardless of whether General Mills, Colgate-Palmolive, and Unilever are co-covered in the article about Kellogg's announcement, there will be overreaction in information transfers between these three firms because of heightened investor attention. To rule out this explanation, for each news article in the main sample, I identify a corresponding placebo article where (1) it covers the earnings announcement of the same firm as the original article; (2) firm-pair $i-j$ are not mentioned in the placebo article (while they are mentioned in the original article) and (3) the placebo article is published at least 400 days after the publication date of the original article so that there is no overlap between the pre-co-coverage window of the placebo article and the post-co-coverage window of the original article. If there are multiple placebo articles that satisfy these criteria, I keep the earliest article. ${ }^{17}$ I then estimate regression (1) using a sample of firm-pair $i-j$ 's earnings announcements before and after the publication of the placebo article to test if focal firm $i$ overreacts to peer $j$ 's announcement when neither of them are mentioned in the placebo article, even if the placebo article covers the earnings announcement of the same firm as the original article where $i$ and $j$ are co-covered. Similar to the previous placebo test, I require firm $i$ and peer $j$ 's earnings announcements are

\footnotetext{
${ }^{17}$ For example, a placebo article to the article covering Kellogg's earnings announcement would be another article covering Kellogg's earnings announcement that is published at least 400 days after the publication date of the original article in the main sample, and does not mention General Mills, Colgate-Palmolive, and Unilever.
} 
for the same quarter. ${ }^{18}$ All other sample construction procedures are the same as those described in Table 1.

The estimation results are presented in Panel B of Table 8. The coefficients on both EXRET_P* AFTER and EXRET_P*BEFORE are statistically insignificant, suggesting that firm $i$ does not overreact to peer $j$ 's earnings either before or after the publication of the placebo article. The coefficient on EXRET * AFTER is insignificant while the coefficient on EXRET * BEFORE is significantly positive. The evidence of return continuation of the focal firm before the placebo article is published (but not after) seems to suggest that investors indeed pay more attention to peer $j$ 's announcement after the publication of the placebo article, but not to the extent of overreacting to its earnings news.

\subsubsection{Risk-based explanation}

A third alternative explanation is that the negative relationship between the co-covered firms' announcement returns is not due to overreaction, but due to cross-sectional variation in the focal firm's exposure to systematic risks with the co-covered peer's announcement return. For example, if good news from the peer implies lower risks for firms that announce earnings subsequently, higher peer announcement return will be associated with lower focal firm announcement and vice versa. This risk-based explanation entails that the negative return predictability is stronger (weaker) when the peer's earnings surprise and the focal firm's expected earnings surprise have different (the same) signs. To rule out this explanation, I conduct a test in the spirit of Ramnath (2002) (Table 7, Panel B) and estimate regression (1) in subsamples where the earnings surprise of the co-covered peer and the expected earnings surprise of the focal firm have the same versus different signs. The expected earnings surprise of the focal firm is calculated as the predicted value from regressing the focal firm's earnings surprise on the peer's earnings surprise, estimated separately for the pre- and post-co-coverage period to control for any potential differences across the two periods in the properties of analyst earnings forecasts used to calculate earnings surprise. ${ }^{19}$

\footnotetext{
${ }^{18}$ Untabulated results suggest that inferences are similar if I do not impose this requirement.

${ }^{19}$ Untabulated results show that inferences remain the same if I calculate the focal firm's expected earnings surprise using the predicted value from regressing the focal firm's earnings surprise on the peer's earnings surprise over the full sample without partitioning by the pre and post period.
} 
The estimation results are tabulated in Panel C of Table 8. In Column (1) and (2) where the regression is estimated using the same-sign subsample, the coefficient on EXRET_P * AFTER is significantly negative, suggesting that the negative return predictability still exists when the focal firm's expected surprise and the peer's surprise have the same sign. In Column (3) and (4) where the regression is estimated using the different-sign subsample, the coefficient on EXRET_P*AFTER is statistically insignificant. These findings run counter to the prediction of the risk-based explanation and is consistent with the behavioral explanation that investors overreact to a co-covered peer's earnings news due to media co-coverage, as behavioral biases tend to be magnified when investors observe signals that confirm their belief (e.g., Daniel, Hirshleifer and Subrahmanyam 1998). In the pre-co-coverage period, investors tend to underreact to the peer's earnings news in the same-sign subsample, as evidenced by the significantly positive coefficient on EXRET_P*BEFORE in Column (1) and (2). In the different-sign subsample, there is no evidence of underreaction, as the coefficient on $E X R E T_{-} P * B E F O R E$ is statistically insignificant. These results are consistent with the findings in Ramnath (2002) that underreaction in information transfers is stronger when the earnings surprises of the two firms have the same signs. Taken together, findings in Table 8 provide support to the hypothesis that the negative relationship between two co-covered firms' announcement returns is due to co-coverage, rather than media coverage increasing the salience of the firms or cross-sectional variation in risks.

\section{Conclusion}

This paper examines the effects of media co-coverage on the efficiency with which investors use peer information to evaluate a firm's performance in the context of earnings announcement information transfers. Using a sample of co-covered firms from earnings-announcement-related news articles published by the WSJ from 2004 to 2016, I find that investors of firms mentioned in the article tend to overreact to the earnings news of an early-announcing co-covered peer, as evidenced by a statistically significant and economically meaningful negative relationship between the two firms' earnings announcement returns. Furthermore, the negative return predictability exists only in the period after the two firms are mentioned in the same article but not in the period before co-coverage occurs, suggesting that the observed negative 
relationship in announcement returns is unlikely to be driven by intrinsic characteristics of the firms being co-covered in WSJ articles. Additional analyses suggest that the overreaction is stronger when investors are more likely to pay attention to the news article where the two firms are co-covered, and when the co-covered peer's earnings announcement is more relevant to the focal firm in information transfers. A battery of tests are performed to ensure that the negative correlation in announcement returns is not due to a mere media coverage effect that increases the salience of firms or exposure to systematic risks. Overall, findings in this paper suggests that media co-coverage can have a significant effect on investors' perception about the relatedness between two firms, which can lead to suboptimal trading decisions in the stock market. 


\section{References}

Adamy, J. “Kellogg 3Q Net Up; Raises Forecast for 2004.” Wall Street Journal (2004).

Barber, B., and Odean, T. "All That Glitters: The Effect of Attention and News on the Buying Behavior of Individual and Institutional Investors." Review of Financial Studies 21 (2008): 785-818.

Barberis, N., Shleifer, A., and Wurgler, J. “Comovement.” Journal of Financial Economics 75 (2005): 283317.

Beaver, W. H., McNichols, M. F., and Wang, Z. Z. "Increased Market Response to Earnings Announcements in the $21^{\text {st }}$ Century: An Empirical Investigation." Journal of Accounting and Economics 69 (2020): 1-21.

Bernard, V. L. and Thomas, J. K. "Evidence that Stock Prices Do Not Fully Reflect the Implications of Current Earnings for Future Earnings." Journal of Accounting and Economics 13 (1990): 305-340.

Bhojraj, S., and Lee, C. M. C. "Who is My Peer? A Valuation-Based Approach to the Selection of Comparable Firms." Journal of Accounting Research 40 (2002): 407-439.

Boehmer, E., Jones, C., Zhang, X., and Zhang, X. "Tracking Retail Investor Activity.” Working paper, Singapore Management University, 2019.

Boyer, B. "Style-related Comovement: Fundamentals or Labels?” Journal of Finance 66 (2011): 307-332.

Call, A. C., Emett, S. A., Maksymov, E., and Sharp, N.Y. "Meet the Press: Survey Evidence on Financial Journalists as Information Intermediaries.” Working paper, Arizona State University, 2020.

Carhart, M. M. “On Persistence in Mutual Fund Performance.” Journal of Finance 52 (1997): 57-82.

Daniel, L., Hirshleifer, D., and Subrahmanyam, A. "Investor Psychology and Security Market Under- and Overreactions.” Journal of Finance 53 (1998): 1839-1886.

Daniel, L., Hirshleifer, D., and Subrahmanyam, A. "Overconfidence, Arbitrage, and Equilibrium Asset Pricing." Journal of Finance 56 (2001): 921-965.

Chan, L.K.C., Lakonishok, J., Swaminathan, B. "Industry Classifications and Return Comovement." Financial Analysts Journal 63 (2007),56-70.

Engelberg, J. E., and Parsons, C. A. "The Causal Impact of Media in Financial Markets." Journal of Finance 66 (2011): 67-97.

Fama, E. F., French, K. R. “Industry Costs of Equity.” Journal of Financial Economics 43 (1997): 153-193.

Fang, L., and Peress J. "Media Coverage and the Cross-section of Stock Returns." Journal of Finance 64 (2009): 2023-2052.

Foster, G. "Intra-industry Information Transfers Associated with Earnings Releases". Journal of Accounting and Economics 3 (1981): 201-232.

French, K. R. and Poterba, J. M. "Investor Diversification and International Equity Markets." American Economic Review 81 (1991): 222-226.

Gibbons, R., and Kevin J. M. "Relative Performance Evaluation for Chief Executive Officers." ILR Review 43 (1990): 30-S.

Green, T., and Hwang, B. "Price-based Return Comovement." Journal of Financial Economics 93 (2009): 37-50. 
Greenwood, R. "Excess Comovement of Stock Returns: Evidence from Cross-Sectional Variation in Nikkei 225 Weights." Review of Financial Studies 21 (2007): 1153-86.

Guest, N. “Do Journalists Help Investors Analyze Firms' Earnings News?” Working paper, Cornell University, 2019.

Hillert, A., Jacobs, H., and Müller, S. “Media Makes Momentum” Review of Financial Studies 27 (2014): 3467-3501.

Hirshleifer, D., Teoh, S. H. "Limited Attention, Information Disclosure, and Financial Reporting." Journal of Accounting and Economics 36 (2003): 337-386.

Hirshleifer, D., Lim, S., and Teoh, S. "Driven to Distraction: Extraneous Events and Underreaction to Earnings News." Journal of Finance 64 (2009): 2289-2325.

Hoberg, G., Phillips, G. "Product Market Synergies and Competition in Mergers and Acquisitions: A Testbased Analysis." Review of Financial Studies 23 (2010): 3773-3811.

Hoberg, G., Phillips, G. “Text-based Network Industries and Endogenous Product Differentiation.” Journal of Political Economy 124 (2016): 1423-1465.

Hong, H., Stein, J. C. "A Unified Theory of Underreaction, Momentum Trading, and Overreaction in Asset Markets." Journal of Finance 54 (1999): 2143-2184.

Huberman, G., and Regev, T. "Contagious Speculation and a Cure for Cancer: A Nonevent That Made Stock Prices Soar.” Journal of Finance 56 (2001): 387-96.

Ikenberry, D. L., Lakonishok, J., and Vermaelen, T. "Market Underreaction to Open Market Share Repurchases.” Journal of Financial Economics 39 (1995): 181-208.

Ikenberry, D. L., Rankine, G., and Stice, E. K. “What Do Stock Splits Really Signal?” Journal of Financial and Quantitative Analysis 31 (1996): 357-375.

Kaniel, R., and Parham, R. "WSJ Category Kings - The Impact of Media Attention on Consumer and Mutual Fund Investment Decisions." Journal of Financial Economics 123 (2017): 337-56.

Kim, Y., Lacina, M., and Park. M. S. "Positive and Negative Information Transfers from Management Forecasts.” Journal of Accounting Research 46 (2008): 885-908.

Koester, A., Lundholm, R., and Soliman, M. "Attracting Attention in a Limited Attention World: Exploring the Causes and Consequences of Extreme Positive Earnings Surprises." Management Science 62 (2016): 2765-3084.

Lee, C.M.C., Ma, P., and Wang, C.C.Y. "Search-based Peer Firm: Aggregating Investor Perceptions through Internet Co-searches." Journal of Financial Economics 116 (2015): 410-31.

Loughran, T. and Ritter, J. R. “The New Issues Puzzle.” Journal of Finance 50 (1995): 23-51.

Lyle, M. R., Stephan, A., and Yohn, T. L. "The Speed of the Market Reaction to Pre-open versus Post-close Earnings Announcements.” Working paper, Northwestern University 2020.

Mishkin, F. “A Rational Expectations Approach to Macro-econometrics: Testing Policy Effectiveness and Efficient Markets Models." Chicago, IL: University of Chicago Press for the National Bureau of Economic Research, 1983.

Peress, J. "Media Coverage and Investors' Attention to Earnings Announcements." Working paper, INSEAD, 2008. 
Peress, J. "The Media and the Diffusion of Information in Financial Markets: Evidence from Newspaper Strikes.” Journal of Finance 69 (2014): 2007-43.

Petersen, M. A. "Estimating Standard Errors in Finance Panel Data Sets: Comparing Approaches." Review of Financial Studies 22 (2009): 435-80.

Ramnath, S. "Investor and Analyst Reactions to Earnings Announcements of Related Firms: An Empirical Analysis." Journal of Accounting Research 40 (2002): 1351-1376.

So, E. C., Wang, S. "News-driven Return Reversals: Liquidity Provision Ahead of Earnings Announcements.” Journal of Financial Economics 114 (2014): 20-35.

Solomon, D., Soltes, E., and Sosyura, D. "Winners in the Spotlight: Media Coverage of Fund Holdings as a Driver of Flows." Journal of Financial Economics 113 (2017): 53-72.

Tetlock, P.C. "Does Public Financial News Resolve Asymmetric Information?" Review of Financial Studies 23 (2010): 3520-3557.

Tetlock, P. C. “All the News That's Fit to Reprint: Do Investors React to Stale Information?” Review of Financial Studies 24 (2011): 1481-1512.

Thomas, J., and Zhang, F. X. "Overreaction to Intra-industry Information Transfers?" Journal of Accounting Research 46 (2008), 909-940.

Wang, C. "Accounting Standards Harmonization and Financial Statement Comparability: Evidence from Transnational Information Transfer." Journal of Accounting Research 52 (2014): 955-992.

Zhang, F. X. "Information Uncertainty and Stock Returns.” Journal of Finance 61 (2006): 105-137. 


\section{Appendix A: Examples of Media Co-coverage}

Example 1

"UMC 2Q Net Profit Surges as Revenue Jumps 34\%" (The Wall Street Journal, 2004-07-28, by Jason Dean)

"United Microelectronics Corp. [emphasis added] announced its biggest quarterly profit in more than three years but gave a hazy outlook for the rest of the year that is unlikely to quell widespread jitters about the technology industry.... UMC makes chips used in a broad range of electronic gadgets for companies such as Texas Instruments Inc. and Xilinx Inc. [emphasis added]"

In this example, the central story of the article is the earnings announcement of United Microelectronics Corp. (UMC). Texas Instruments Inc. and Xilinx Inc. were co-covered as background information.

\section{Example 2}

"ChevronTexaco’s Quarterly Profit Edged Up 4\%" (The Wall Street Journal, 2005-05-01, by Russell Gold)

"ChevronTexaco Corp. [emphasis added] posted a modest $4 \%$ increase in first-quarter profit, even as most of its peers reported surges in net income amid record oil and natural-gas prices. The second-largest U.S. oil company behind Exxon Mobil Corp. [emphasis added] reported that gains from soaring commodity prices mostly were offset by poor performance in the refining segment and declining energy production.... Investors also were encouraged by strong results posted Thursday by oil-and-gas producer Unocal Corp., [emphasis added] which ChevronTexaco agreed to acquire last month in a $\$ 16.8$ billion cash-and-stock deal."

In this case, ChevronTexaco Corp.'s earnings announcement is the main story of the article. Exxon Mobil Corp. and Unocal are the co-covered firms.

Example 3

"Philips Electronics 2Q Profit Falls 94\%" (The Wall Street Journal, 2009-07-13, by Robin van Daalen)

"Philips Electronics $N V$ [emphasis added] posted a 94\% drop in second-quarter profit and said it plans to intensify cost-cutting efforts even as markets are showing some signs of stabilizing. The Netherlands-based company also said it received cartel charges from the European Commission in May citing alleged pricefixing by one of its former units, LG Philips LCD Co. Philips sold its remaining shareholding in the company, now called LG Display Co., [emphasis added] in March. South Korea-based LG Display said it is studying the details of the charges... Philips said its net profit declined to 44 million euros (\$61 million) in the three months ended June 30 from 732 million euros a year earlier. The year-earlier results were lifted by gains of 533 million euros after Philips sold shares in computer-chip maker TSMC Ltd. [Taiwan Semiconductor Manufacturing Co. Ltd., emphasis added]."

In this example, the main story of the article is Philips Electronics NV's earnings announcement, and LG Display Co. and TSMC Ltd are the co-covered firms. 


\section{Appendix B. Algebraic Illustration of the Return Predictability in Information Transfers}

Using the framework of Mishkin (1983), suppose that the relationship between the focal firm's earnings and the co-covered peer's earnings is provided by the following model:

$$
\text { EARNINGS_FOCAL } L_{q}=a_{0}+a_{1} * \text { EARNINGS_PEER }{ }_{q}+\varepsilon_{q},
$$

where EARNINGS_FOCAL $L_{q}\left(E A R N I N G S \_P E E R_{q}\right)$ is the earnings of the focal firm (co-covered peer) in quarter $q . a_{1}$ captures the correlation between the two firms' earnings and is determined by their economic relatedness.

In efficient market where abnormal returns are expected to be zero, the return of the focal firm on its own earnings announcement day can be described as

$$
\text { EXRET_OWN } N_{q}=b e t a *\left(E A R N I N G S \_F O C A L_{q}-a_{0}{ }_{0}-a^{\prime}{ }_{1} * E A R N I N G S \_P E E R_{q}\right)+\varepsilon_{q} \text {, }
$$

where EXRET_OWN is the market-adjusted one-day return of the focal firm on its own earnings announcement day. beta is the earnings response coefficient and $a^{\prime}{ }_{1}$ captures investors' perceived relatedness between the focal firm and the peer as implied by the price change around the focal firm's earnings announcement.

Similarly, the peer's announcement return can be described as

$$
E X R E T \_P_{q}=b e t a *\left(E A R N I N G S \_P E E R_{q}-E\left(E A R N I N G S \_P E E R_{q} \mid \phi_{t}\right)\right)+\varepsilon_{q},
$$

where $E X R E T P_{q}$ is the market-adjusted one-day return of the co-covered peer on its own earnings announcement day. E(EARNINGS_PEER $\left.q \mid \phi_{t}\right)$ is the market's expectation of the peer's quarter $q$ earnings given the information set available before its announcement day $t$.

Rearranging equation (i), (ii) and (iii) gives the following:

$$
\text { EXRET_OWN } N_{q}=\operatorname{beta}^{*}\left(\left(a_{0}-a_{0}^{\prime}\right)+\left(a_{1}-a^{\prime}{ }_{1}\right) *\left(\frac{\text { EXRET_P }_{q}-\varepsilon_{q}}{\text { beta }}+E\left(\text { EARNINGS_PEER }_{q} \mid \phi_{t}\right)\right)+\right.
$$

$$
\left.\varepsilon_{q}\right)+\varepsilon_{q}
$$

As the earnings response coefficient beta is in general positive, EXRET_P $P_{q}$ should be negatively correlated with EXRET_OWN $\mathrm{O}_{q}$ if $a^{\prime}{ }_{1}>a_{1}$. 


\section{Figure 1. Illustration of the Timeline in the Information Transfer Tests}

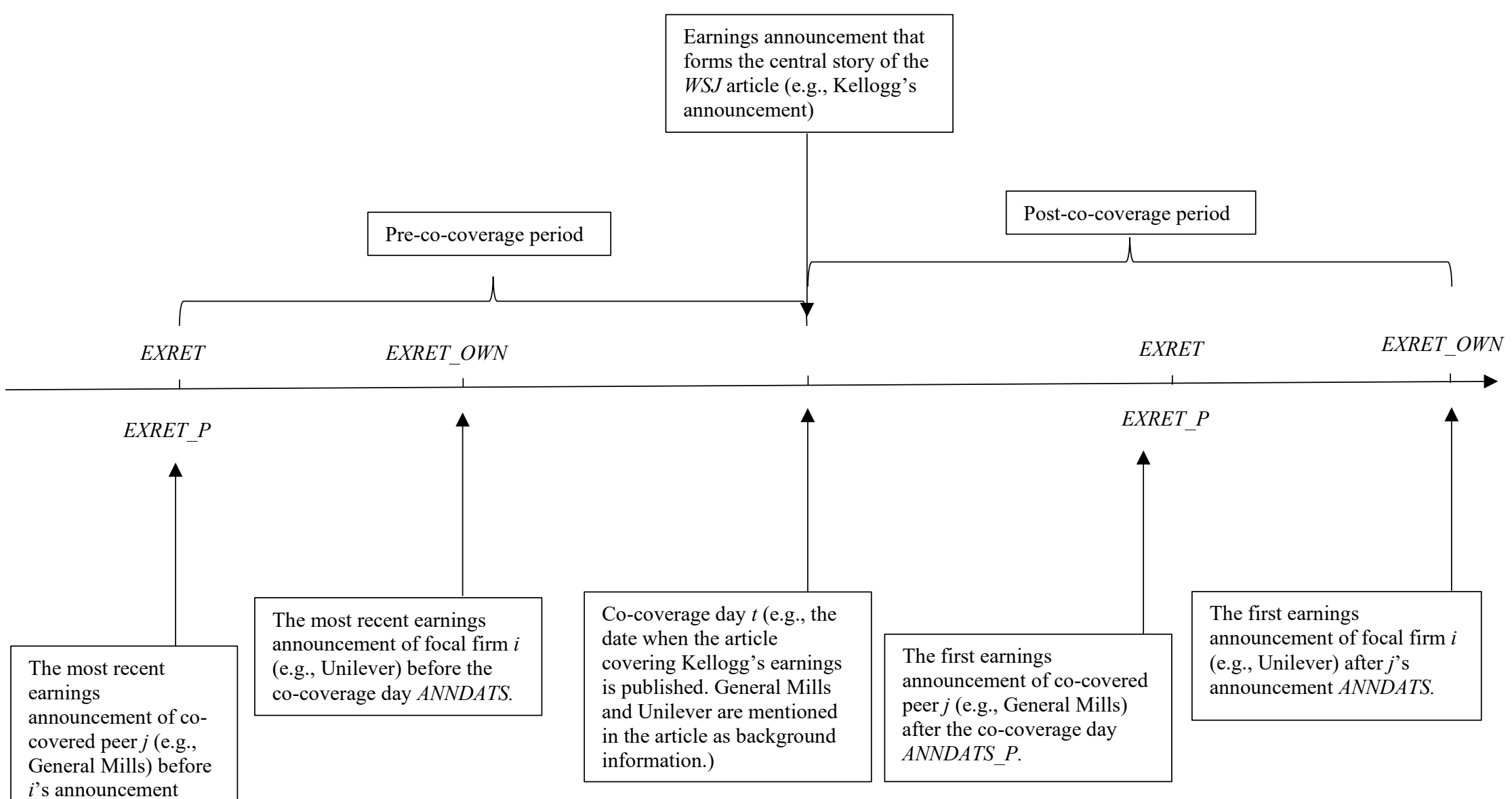


TABLE 1

Media Co-coverage Sample Construction

\begin{tabular}{|c|c|c|c|}
\hline Steps & No. of articles & No. of firms & No. of firm-pairs \\
\hline (1) $W S J$ full articles about firms' earnings announcement from the RavenPack database & 5,984 & 17,265 & 51,694 \\
\hline (2) If a firm-pair is co-covered in multiple articles during the same day, keep the earliest article. & 3,752 & 13,149 & 42,040 \\
\hline (3) Drop financial firms, publishing firms, and research firms & 2,428 & 7,403 & 18,921 \\
\hline (4) Drop firm-pairs where the two firms belong to the same business group & 2,426 & 7,399 & 18,905 \\
\hline (5) Drop firm-pairs where at least one of the firms is a non-US firm & 1,739 & 4,813 & 10,374 \\
\hline $\begin{array}{l}\text { (6) For each firm-pair } i \text { (focal firm) - } j \text { (the co-coverage peer), merge with } j \text { 's first earnings } \\
\text { announcement following the article publication day }\left(A N N D A T S \_P \text { ), and } i \text { 's first earnings }\right. \\
\text { announcement following } j \text { 's earnings announcement day }(A N N D A T S) \text {. }\end{array}$ & 1,461 & 3,840 & 7,530 \\
\hline $\begin{array}{l}\text { (7) Drop firm-pairs where the article publication day and the two firm's earnings } \\
\text { announcement dates are too far apart, i.e., where (a) the fiscal quarter ends of the focal firm } \\
\text { and the co-covered peer are more than } 3 \text { months apart; or (b) the number of days between } \\
\text { article publication day and ANNDATS_P is more than } 100 \text { days; or (c) the number of days } \\
\text { between the article publication day and } A N N D A T S \text { is more than } 200 \text { days. }\end{array}$ & 1,441 & 3,708 & 7,199 \\
\hline $\begin{array}{l}\text { (8) Drop firm-pairs where at least one of the firms was featured as the main story of a WSJ } \\
\text { article for any type of economic events during }[t-100, A N N D A T S] \text {, where } t \text { is the article } \\
\text { publication day. }\end{array}$ & 688 & 1,612 & 2,673 \\
\hline $\begin{array}{l}\text { (9) Drop firm-pairs where the two firms have co-appeared in other } W S J \text { articles during }[t-100 \text {, } \\
\text { ANNDATS }] \text {, where } t \text { is the article publication day. }\end{array}$ & 684 & 1,605 & 2,656 \\
\hline $\begin{array}{l}\text { (10) Drop firm-pairs that are co-covered in articles where the announcing firm (whose earnings } \\
\text { announcement is the central story of the article) cannot be identified in } \mathrm{I} / \mathrm{B} / \mathrm{E} / \mathrm{S} \text { and CRSP or } \\
\text { is not a US firm. }\end{array}$ & 472 & 1,120 & 1,908 \\
\hline (11) Drop firm-pairs where there is no matched control observation. & 455 & 1,063 & 1,814 \\
\hline
\end{tabular}

Table 1 describes the steps used to construct the media co-coverage sample and the number of observations remaining after each step. 
TABLE 2

Descriptive Statistics

Panel A. Characteristics of the co-covered firms

\begin{tabular}{lllll}
\hline & MKTCAP & BM & INST & ACC \\
\hline Mean & 76,428 & 0.32 & 746.02 & -0.01 \\
Std. & 85,790 & 0.50 & 437.85 & 0.03 \\
P75 & 116,890 & 0.50 & 1,113 & 0 \\
Median & 45,822 & 0.30 & 726 & -0.01 \\
P25 & 10,967 & 0.18 & 357 & -0.02 \\
N & 1,814 & 1,814 & 1,814 & 1,814 \\
\hline
\end{tabular}

Panel B. Comparison between characteristics of co-covered firms and their FF48 industry peers

\begin{tabular}{lllll}
\hline Mean of: & Co-covered firms & FF48 peers & Difference & p-value (two-sided) \\
\hline MKTCAP & 76,428 & 3,620 & $72,808^{* * *}$ & 0.00 \\
$B M$ & 0.32 & 2.36 & $-2.04^{* * *}$ & 0.00 \\
$I N S T$ & 746.02 & 123.63 & $622.39^{* * *}$ & 0.00 \\
$A C C$ & -0.01 & -0.01 & 0.00 & 0.89 \\
\hline
\end{tabular}

Panel C. Earnings announcement variables

\begin{tabular}{llllcc}
\hline & & $\begin{array}{l}\text { SURP } \\
\text { (multiplied by 100) }\end{array}$ & \multicolumn{3}{c}{$\begin{array}{c}\text { EXRET_OWN } \\
\text { (returns in percentages) }\end{array}$} \\
\hline Post-co-coverage & Mean & 0.09 & -0.02 & 0.03 & -0.04 \\
& Std. & 0.64 & 6.41 & 6.39 & 2.26 \\
& P75 & 0.21 & 3.20 & 3.34 & 0.91 \\
& Median & 0.07 & 0.08 & 0.23 & -0.07 \\
& P25 & -0.01 & -2.59 & -2.54 & -0.94 \\
N & 1814 & 1814 & 1814 & 1814 \\
& & & & & \\
Pre-co-coverage & Mean & 0.12 & -0.48 & -0.16 & 0.06 \\
& Std. & 0.56 & 5.74 & 6.20 & 2.36 \\
& P75 & 0.19 & 2.41 & 2.88 & 0.95 \\
Median & 0.06 & -0.40 & 0.12 & -0.02 \\
P25 & 0.00 & -2.88 & -2.67 & -0.88 \\
N & 1814 & 1814 & 1814 & 1814 \\
\hline
\end{tabular}

Table 2 reports descriptive statistics of the sample. Panel A presents summary statistics on the characteristics of the co-covered firms. Panel B compares the characteristics of the co-covered firms to those of their FF48 industry peers. Panel C reports statistics of the earnings announcement window variables. SURP is the co-covered firms' earnings surprise, scaled by lagged market capitalization. EXRET_OWN is the focal firm's announcement excess return. EXRET_P is the co-covered peer's announcement excess return. EXRET is the focal firm's excess return on the peer's announcement day. 
TABLE 3

Univariate Analysis

Panel A. Correlation between earnings announcement window returns

\begin{tabular}{|c|c|c|c|c|}
\hline \multicolumn{2}{|c|}{ (p-values in parentheses) } & EXRET_P & EXRET & EXRET_OWN \\
\hline \multirow[t]{7}{*}{ Post-co-coverage } & \multirow[t]{2}{*}{ EXRET_P } & & $0.11 * * *$ & $-0.05^{* *}$ \\
\hline & & & $(0.00)$ & $(0.03)$ \\
\hline & \multirow[t]{2}{*}{ EXRET } & $0.18 * * *$ & & 0.03 \\
\hline & & $(0.00)$ & & $(0.20)$ \\
\hline & \multirow[t]{2}{*}{ EXRET_OWN } & $-0.05 * *$ & -0.04 & \\
\hline & & $(0.04)$ & $(0.13)$ & \\
\hline & $\mathrm{N}$ & 1,814 & 1,814 & 1,814 \\
\hline \multirow[t]{7}{*}{ Pre-co-coverage } & \multirow[t]{2}{*}{ EXRET_P } & & $0.18 * * *$ & 0.04 \\
\hline & & & $(0.00)$ & $(0.12)$ \\
\hline & \multirow[t]{2}{*}{ EXRET } & $0.20 * * *$ & & 0.02 \\
\hline & & $(0.00)$ & & $(0.33)$ \\
\hline & \multirow[t]{2}{*}{ EXRET_OWN } & 0.02 & 0.01 & \\
\hline & & $(0.43)$ & $(0.58)$ & \\
\hline & $\mathrm{N}$ & 1,814 & 1,814 & 1,814 \\
\hline
\end{tabular}

Panel B. Hedge returns from longing (shorting) firms in the lowest (highest) $E X R E T \_P$ decile

\begin{tabular}{lllll}
\hline (returns in percentages) & \multicolumn{2}{c}{ Post-co-coverage } & \multicolumn{2}{c}{ Pre-co-coverage } \\
\hline & $E X R E T \_P$ & $E X R E T \_O W N$ & EXRET_P & EXRET_OWN \\
\cline { 2 - 5 } $\begin{array}{l}\text { Lowest decile based on sample } \\
\text { distribution of EXRET_P(low) }\end{array}$ & -12.51 & 0.69 & -12.42 & -0.38 \\
$\begin{array}{l}\text { Highest decile based on sample } \\
\text { distribution of EXRET_P(high) }\end{array}$ & 11.02 & 0.06 & 10.57 & -0.02 \\
& & & & \\
Low - High & & $0.63 *$ & -0.37 \\
p-value (two-sided) based on & 0.08 & 0.25 \\
Newey-West standard error & & & & \\
$\mathrm{N}$ & 476 & 476 & 450 & 450 \\
\hline
\end{tabular}

Panel C. Abnormal returns from the hedging strategy in the post-co-coverage period after adjusting for common risk factors

\begin{tabular}{lll}
\hline (returns in percentages) & \multicolumn{2}{c}{ EXRET_OWN (low - high) } \\
\hline & Coef. & p-value (two-sided) \\
\cline { 2 - 3 } Alpha (b0) & $0.62^{* *}$ & 0.03 \\
mktrf (b1) & -44.51 & 0.14 \\
smb (b2) & $94.41^{*}$ & 0.07 \\
\hline
\end{tabular}




\begin{tabular}{lll}
\hline $\mathrm{hml}(\mathrm{b} 3)$ & 34.14 & 0.60 \\
umd (b4) & 34.14 & 0.63 \\
$\mathrm{~N}$ & 238 & \\
\hline
\end{tabular}

Table 3 presents results from univariate analysis on the relationship between the an early-announcing cocovered peer's announcement excess return EXRET $P$ and the focal firm's own announcement excess return EXRET_OWN. Panel A reports the Pearson (upper half) and Spearman (lower half) correlation between EXRET_P, EXRET_OWN and the focal firm's excess return on the peer's announcement day EXRET. Panel B presents the hedge return from long (shorting) firms in the lowest (highest) decile of EXRET_P based on sample distribution. p-values (two-sided) are based on Newey-West standard errors. Panel $\mathrm{C}$ reports the estimation results from regressing the hedge portfolio returns in the post-co-coverage period on the market, size, book-to-market and momentum factors. p-values (two-sided) are based on Newey-West standard errors. *, **, and $* * *$ represent significance levels at $10 \%, 5 \%$, and $1 \%$, respectively. 
TABLE 4

Regression Analysis on the Relationship between Co-covered Firms' Announcement Returns

\begin{tabular}{|c|c|c|}
\hline & (1) & (2) \\
\hline \multirow{3}{*}{$\begin{array}{l}\text { (t-stats in brackets) } \\
\boldsymbol{E X R E T \_ P} * \boldsymbol{A F T E R}\end{array}$} & EXRET_OWN & EXRET_OWN \\
\hline & $-0.05^{*}$ & $-0.05^{* * *}$ \\
\hline & {$[-1.91]$} & {$[-2.39]$} \\
\hline \multirow[t]{2}{*}{ EXRET_P ${ }^{*}$ BEFORE } & 0.04 & 0.03 \\
\hline & {$[1.26]$} & [1.01] \\
\hline \multirow[t]{2}{*}{ EXRET * AFTER } & 0.09 & 0.08 \\
\hline & {$[0.87]$} & [0.79] \\
\hline \multirow[t]{2}{*}{ EXRET * BEFORE } & 0.00 & -0.01 \\
\hline & [0.05] & {$[-0.09]$} \\
\hline \multirow[t]{2}{*}{ AFTER } & 0.00 & 0.00 \\
\hline & [1.31] & [1.02] \\
\hline \multirow[t]{2}{*}{ SURP } & $1.30^{* *}$ & $1.52 * *$ \\
\hline & [2.45] & {$[2.57]$} \\
\hline \multirow[t]{2}{*}{$L O G \_M K T C A P$} & 0.00 & $0.00 * *$ \\
\hline & [1.43] & {$[2.01]$} \\
\hline \multirow[t]{2}{*}{$A C C$} & 0.01 & 0.01 \\
\hline & {$[0.18]$} & {$[0.21]$} \\
\hline \multirow[t]{2}{*}{$B M$} & 0.00 & 0.00 \\
\hline & [1.03] & [0.98] \\
\hline \multirow[t]{2}{*}{ PREEXRET } & -0.01 & 0.01 \\
\hline & {$[-0.17]$} & {$[0.09]$} \\
\hline \multirow[t]{2}{*}{ MOMENTUM } & -0.01 & -0.00 \\
\hline & {$[-0.89]$} & {$[-0.44]$} \\
\hline Industry FE & No & Yes \\
\hline Year FE & No & Yes \\
\hline $\mathrm{N}$ & 3628 & 3628 \\
\hline RSQ & 0.024 & 0.054 \\
\hline adj. RSQ & 0.021 & 0.038 \\
\hline
\end{tabular}

Table 4 provides regression results on the relationship between the co-covered firms' announcement returns. EXRET_OWN is the focal firm's announcement excess return. EXRET_P is the early-announcing peer's announcement excess return. AFTER (BEFORE) is an indicator variable that is equal to 1 if an observation is from the post- (pre-) co-coverage period, and 0 otherwise. EXRET is the focal firm's excess return on the peer's announcement day. SURP is the earnings surprise of the focal firm, scaled by lagged market capitalization. $L O G_{-} M K T C A P$ is the natural logarithm of the focal firm's market capitalization as of the end of the previous fiscal quarter. $A C C$ is the total accruals of the focal firm as of the end of the previous fiscal quarter. $B M$ is the book-to-market ratio of the focal firm as of the end of the previous fiscal quarter. PREEXRET is the cumulated market-adjusted excess return of the focal firm over a three-day window ending two days before its earnings announcement day. MOMENTUM is the cumulative market-adjusted excess return of the focal firm over a ninety-day window ending five days before its earnings announcement. Industry fixed effects are based on the focal firm's FF48 industry. Standard errors are clustered by firm and quarter. $* * *$, and $* * *$ represent significance levels at $10 \%, 5 \%$, and $1 \%$, respectively. 
TABLE 5

Effects of Media Co-coverage by Investor Attention to the Article

\begin{tabular}{|c|c|c|c|c|}
\hline \multirow[t]{2}{*}{ ATT based on: } & \multicolumn{2}{|c|}{ Abnormal return volatility } & \multicolumn{2}{|c|}{ Announcement and publication timing } \\
\hline & $(1)$ & $(2)$ & (3) & $(4)$ \\
\hline (t-stats in brackets) & EXRET_OWN & EXRET_OWN & EXRET_OWN & EXRET_OWN \\
\hline \multirow[t]{2}{*}{$E X R E T \_P * A F T E R * A T T$} & $-0.06 *$ & $-0.05 *$ & $-0.12 * *$ & $-0.11 * *$ \\
\hline & {$[-1.79]$} & {$[-1.70]$} & {$[-2.26]$} & {$[-2.31]$} \\
\hline \multirow[t]{2}{*}{ EXRET_P*AFTER } & -0.02 & -0.03 & 0.06 & 0.05 \\
\hline & {$[-0.69]$} & {$[-1.17]$} & {$[1.03]$} & {$[0.90]$} \\
\hline \multirow[t]{2}{*}{$E X R E T \_P * B E F O R E * A T T$} & -0.07 & $-0.09 *$ & 0.04 & 0.06 \\
\hline & {$[-1.59]$} & {$[-1.79]$} & {$[0.56]$} & {$[0.82]$} \\
\hline \multirow[t]{2}{*}{$E X R E T \_P * B E F O R E$} & $0.08 *$ & $0.08 *$ & $\mathbf{0 . 0 0}$ & -0.02 \\
\hline & [1.77] & {$[1.74]$} & {$[0.06]$} & {$[-0.36]$} \\
\hline \multirow[t]{2}{*}{$A F T E R * A T T$} & 0.01 & 0.01 & -0.00 & -0.00 \\
\hline & {$[0.81]$} & {$[0.90]$} & {$[-0.52]$} & {$[-0.36]$} \\
\hline \multirow[t]{2}{*}{$A T T$} & -0.01 & -0.01 & -0.01 & -0.01 \\
\hline & {$[-0.92]$} & {$[-0.95]$} & {$[-1.54]$} & {$[-0.94]$} \\
\hline \multirow[t]{2}{*}{ EXRET * AFTER } & 0.08 & 0.08 & 0.10 & 0.09 \\
\hline & {$[0.84]$} & {$[0.78]$} & {$[0.98]$} & {$[0.90]$} \\
\hline \multirow[t]{2}{*}{ EXRET * BEFORE } & 0.02 & 0.00 & 0.00 & -0.01 \\
\hline & {$[0.17]$} & {$[0.03]$} & {$[0.03]$} & {$[-0.08]$} \\
\hline \multirow[t]{2}{*}{ AFTER } & 0.00 & 0.00 & $0.01^{*}$ & 0.01 \\
\hline & {$[0.26]$} & {$[0.17]$} & {$[1.68]$} & [1.19] \\
\hline \multirow[t]{2}{*}{$S U R P$} & $1.30 * *$ & $1.52 * *$ & $1.35^{* *}$ & $1.53 * *$ \\
\hline & {$[2.50]$} & {$[2.62]$} & {$[2.58]$} & {$[2.67]$} \\
\hline \multirow[t]{2}{*}{$L O G \_M K T C A P$} & 0.00 & $0.00 *$ & 0.00 & $0.00 * *$ \\
\hline & {$[1.16]$} & {$[1.98]$} & {$[1.60]$} & {$[2.03]$} \\
\hline \multirow[t]{2}{*}{$A C C$} & 0.01 & 0.01 & 0.02 & 0.02 \\
\hline & {$[0.21]$} & {$[0.23]$} & {$[0.25]$} & {$[0.24]$} \\
\hline \multirow[t]{2}{*}{$B M$} & 0.00 & 0.00 & 0.00 & 0.00 \\
\hline & {$[0.99]$} & {$[0.97]$} & {$[1.07]$} & {$[1.03]$} \\
\hline
\end{tabular}




\begin{tabular}{lllll}
\hline PREEXRET & -0.01 & 0.01 & -0.01 & 0.00 \\
MOMENTUM & {$[-0.15]$} & {$[0.10]$} & {$[-0.19]$} & {$[0.05]$} \\
& -0.01 & -0.00 & -0.01 & -0.00 \\
Industry FE & {$[-0.94]$} & {$[-0.51]$} & {$[-0.93]$} & Yes \\
Year FE & No & Yes & No & Yes \\
N & No & Yes & & 3628 \\
RSQ & & & 3628 & 0.057 \\
adj. RSQ & 3628 & 3628 & 0.029 & 0.040
\end{tabular}

Table 5 provides evidence on how the effects of media co-coverage vary with investor attention to the article. In Column (1) and (2), an article is regarded as receiving high investor attention $(A T T=1)$ if the abnormal return volatility $(U S T A T)$ of the earnings announcement it covers as central story is above the sample media. Otherwise, it is regarded as receiving low attention $(A T T=0)$. In Column (3) and (4), an article is regarded as receiving high investor attention $(A T T=1)$ if both the earnings announcement covered by the article and the article itself are not published on the same trading day before market closes. Otherwise, it is regarded as receiving low attention $(A T T=0)$. EXRET_OWN is the focal firm's announcement excess return. EXRET_P is the early-announcing peer's announcement excess return. AFTER (BEFORE) is an indicator variable that is equal to 1 if an observation is from the post- (pre-) co-coverage period, and 0 otherwise. EXRET is the focal firm's excess return on the peer's announcement day. SURP is the earnings surprise of the focal firm, scaled by lagged market capitalization. LOG_MKTCAP is the natural logarithm of the focal firm's market capitalization as of the end of the previous fiscal quarter. $A C C$ is the total accruals of the focal firm as of the end of the previous fiscal quarter. $B M$ is the book-to-market ratio of the focal firm as of the end of the previous fiscal quarter. PREEXRET is the cumulated market-adjusted excess return of the focal firm over a three-day window ending two days before its earnings announcement day. MOMENTUM is the cumulative market-adjusted excess return of the focal firm over a ninety-day window ending five days before its earnings announcement. Industry fixed effects are based on the focal firm's FF48 industry. Standard errors are clustered by firm and quarter. *, **, and *** represent significance levels at $10 \%$, $5 \%$, and $1 \%$, respectively. 
TABLE 6

Effects of Media Co-coverage by Peer Earnings Relevance in Information Transfers

\begin{tabular}{|c|c|c|c|c|}
\hline \multirow[t]{2}{*}{$R L V$ based on: } & \multicolumn{2}{|c|}{ Same fiscal quarter } & \multicolumn{2}{|c|}{ Economic relatedness } \\
\hline & $(1)$ & $(2)$ & $(3)$ & $(4)$ \\
\hline (t-stats in brackets) & EXRET_OWN & EXRET_OWN & EXRET_OWN & EXRET_OWN \\
\hline \multirow[t]{2}{*}{$E X R E T \_P * A F T E R * R L V$} & $-0.13 *$ & $-0.14 * *$ & $-0.09 *$ & $-0.09 * *$ \\
\hline & {$[-2.00]$} & {$[-2.04]$} & {$[-1.92]$} & {$[-2.17]$} \\
\hline \multirow[t]{2}{*}{$E X R E T \_P * A F T E R$} & -0.01 & -0.01 & -0.01 & -0.01 \\
\hline & {$[-0.20]$} & {$[-0.40]$} & {$[-0.23]$} & {$[-0.44]$} \\
\hline \multirow[t]{2}{*}{$E X R E T \_P * B E F O R E * R L V$} & -0.03 & -0.05 & -0.04 & -0.06 \\
\hline & {$[-0.72]$} & {$[-1.04]$} & {$[-1.05]$} & {$[-1.21]$} \\
\hline \multirow{2}{*}{$E X R E T \_P * B E F O R E$} & 0.05 & 0.04 & $0.06 *$ & $0.05 *$ \\
\hline & {$[1.42]$} & {$[1.33]$} & {$[1.80]$} & {$[1.68]$} \\
\hline \multirow[t]{2}{*}{$A F T E R * R L V$} & 0.01 & 0.01 & 0.00 & -0.00 \\
\hline & {$[1.25]$} & {$[1.10]$} & {$[0.03]$} & {$[-0.01]$} \\
\hline \multirow[t]{2}{*}{$R L V$} & -0.00 & -0.00 & 0.00 & -0.00 \\
\hline & {$[-0.76]$} & {$[-0.58]$} & {$[0.17]$} & {$[-0.04]$} \\
\hline \multirow[t]{2}{*}{ EXRET * AFTER } & 0.09 & 0.08 & 0.09 & 0.09 \\
\hline & {$[0.88]$} & {$[0.80]$} & {$[0.93]$} & {$[0.85]$} \\
\hline \multirow[t]{2}{*}{ EXRET * BEFORE } & 0.01 & -0.00 & 0.01 & -0.00 \\
\hline & {$[0.12]$} & {$[-0.02]$} & {$[0.10]$} & {$[-0.01]$} \\
\hline \multirow{2}{*}{ AFTER } & 0.00 & 0.00 & 0.00 & 0.00 \\
\hline & {$[0.73]$} & {$[0.50]$} & {$[0.73]$} & {$[0.68]$} \\
\hline \multirow[t]{2}{*}{$S U R P$} & $1.29 * *$ & $1.51^{* *}$ & $1.32 * *$ & $1.54 * *$ \\
\hline & {$[2.44]$} & {$[2.57]$} & {$[2.48]$} & {$[2.60]$} \\
\hline \multirow[t]{2}{*}{$L O G \_M K T C A P$} & 0.00 & $0.00 * *$ & 0.00 & $0.00 *$ \\
\hline & {$[1.42]$} & {$[2.03]$} & {$[1.33]$} & {$[1.95]$} \\
\hline \multirow[t]{2}{*}{$A C C$} & 0.01 & 0.01 & 0.01 & 0.01 \\
\hline & {$[0.22]$} & {$[0.24]$} & {$[0.22]$} & {$[0.24]$} \\
\hline \multirow[t]{2}{*}{$B M$} & 0.00 & 0.00 & 0.00 & 0.00 \\
\hline & {$[0.97]$} & {$[0.93]$} & {$[0.97]$} & {$[1.00]$} \\
\hline \multirow[t]{2}{*}{ PREEXRET } & -0.01 & 0.01 & -0.01 & 0.01 \\
\hline & {$[-0.15]$} & {$[0.10]$} & {$[-0.18]$} & {$[0.08]$} \\
\hline \multirow[t]{2}{*}{ MOMENTUM } & -0.01 & -0.00 & -0.01 & -0.00 \\
\hline & {$[-0.82]$} & {$[-0.36]$} & {$[-0.87]$} & {$[-0.47]$} \\
\hline Industry FE & No & Yes & No & Yes \\
\hline Year FE & No & Yes & No & Yes \\
\hline $\mathrm{N}$ & 3628 & 3628 & 3628 & 3628 \\
\hline RSQ & 0.027 & 0.057 & 0.026 & 0.056 \\
\hline adj. RSQ & 0.023 & 0.040 & 0.022 & 0.039 \\
\hline
\end{tabular}

Table 6 provides evidence on how the effects of media co-coverage vary with the relevance of the earlyannouncing co-covered peer's earnings to the focal firm in information transfers. In Column (1) and (2), a peer's earnings announcement is regarded as having higher relevance if the two firms' earnings are 
measured over the same fiscal quarter $(R L V=1)$. Otherwise, it is considered as having lower relevance $(R L V=0)$. In Column (3) and (4), a peer's earnings announcement is regarded as having higher relevance if the Edgar co-search traffic between the two firms is above industry median $(R L V=1)$. Otherwise, it is considered as having lower relevance $(R L V=0)$. EXRET_OWN is the focal firm's announcement excess return. EXRET_P is the early-announcing peer's announcement excess return. AFTER (BEFORE) is an indicator variable that is equal to 1 if an observation is from the post- (pre-) co-coverage period, and 0 otherwise. EXRET is the focal firm's excess return on the peer's announcement day. SURP is the earnings surprise of the focal firm, scaled by lagged market capitalization. $L O G \_M K T C A P$ is the natural logarithm of the focal firm's market capitalization as of the end of the previous fiscal quarter. $A C C$ is the total accruals of the focal firm as of the end of the previous fiscal quarter. $B M$ is the book-to-market ratio of the focal firm as of the end of the previous fiscal quarter. PREEXRET is the cumulated market-adjusted excess return of the focal firm over a three-day window ending two days before its earnings announcement day. MOMENTUM is the cumulative market-adjusted excess return of the focal firm over a ninety-day window ending five days before its earnings announcement. Industry fixed effects are based on the focal firm's FF48 industry. Standard errors are clustered by firm and quarter. *, **, and *** represent significance levels at $10 \%, 5 \%$, and $1 \%$, respectively. 
TABLE 7

Additional Factors Affecting the Effects of Media Co-coverage

\begin{tabular}{|c|c|c|c|c|c|}
\hline \multicolumn{3}{|c|}{ Focal firm uncertainty } & \multicolumn{3}{|c|}{ Retail investor activity } \\
\hline \multirow[b]{2}{*}{ (t-stats in brackets) } & $(1)$ & $(2)$ & & (3) & (4) \\
\hline & EXRET_OWN & EXRET_OWN & & EXRET_OWN & EXRET_OWN \\
\hline \multirow[t]{2}{*}{ EXRET_P*AFTER *UNC } & $-0.07 *$ & $-0.07 *$ & EXRET_P $* A F T E R * R E T A I L$ & $-0.07 * *$ & $-0.05 *$ \\
\hline & {$[-1.89]$} & {$[-1.86]$} & & {$[-2.01]$} & {$[-1.72]$} \\
\hline \multirow[t]{2}{*}{ EXRET_P*AFTER } & -0.01 & -0.02 & EXRET_P*AFTER & -0.02 & -0.04 \\
\hline & {$[-0.57]$} & {$[-0.92]$} & & {$[-1.03]$} & {$[-1.59]$} \\
\hline \multirow[t]{2}{*}{ EXRET_P $*$ BEFORE *UNC } & $0.09 * *$ & $0.09 * *$ & EXRET_P $*$ BEFORE * RETAIL & -0.01 & -0.02 \\
\hline & {$[2.56]$} & {$[2.54]$} & & {$[-0.25]$} & {$[-0.43]$} \\
\hline \multirow[t]{2}{*}{ EXRET_P * BEFORE } & -0.01 & -0.02 & $E X R E T \_P * B E F O R E$ & 0.04 & 0.04 \\
\hline & {$[-0.29]$} & {$[-0.53]$} & & {$[1.55]$} & {$[1.37]$} \\
\hline \multirow[t]{2}{*}{$A F T E R * U N C$} & -0.01 & -0.01 & AFTER * RETAIL & 0.01 & 0.01 \\
\hline & {$[-1.23]$} & {$[-1.01]$} & & {$[1.27]$} & {$[1.12]$} \\
\hline \multirow[t]{2}{*}{$U N C$} & 0.00 & 0.00 & RETAIL & -0.00 & -0.01 \\
\hline & {$[0.74]$} & {$[0.58]$} & & {$[-0.81]$} & {$[-0.98]$} \\
\hline \multirow[t]{2}{*}{ EXRET * AFTER } & 0.09 & 0.08 & EXRET * AFTER & 0.08 & 0.08 \\
\hline & {$[0.89]$} & {$[0.81]$} & & {$[0.87]$} & {$[0.80]$} \\
\hline \multirow[t]{2}{*}{ EXRET * BEFORE } & -0.00 & -0.02 & EXRET * BEFORE & 0.00 & -0.01 \\
\hline & {$[-0.03]$} & {$[-0.15]$} & & {$[0.05]$} & {$[-0.08]$} \\
\hline \multirow[t]{2}{*}{ AFTER } & 0.01 & 0.01 & AFTER & 0.00 & 0.00 \\
\hline & {$[1.54]$} & {$[1.36]$} & & {$[0.64]$} & {$[0.46]$} \\
\hline \multirow[t]{2}{*}{$S U R P$} & $1.30 * *$ & $1.52 * *$ & SURP & $1.30 * *$ & $1.52 * *$ \\
\hline & {$[2.44]$} & {$[2.57]$} & & {$[2.47]$} & {$[2.60]$} \\
\hline \multirow[t]{2}{*}{$L O G \_M K T C A P$} & 0.00 & $0.00 *$ & $L O G \_M K T C A P$ & 0.00 & $0.00 * *$ \\
\hline & {$[1.31]$} & {$[1.83]$} & & [1.39] & {$[2.04]$} \\
\hline \multirow[t]{2}{*}{$A C C$} & 0.01 & 0.02 & $A C C$ & 0.01 & 0.01 \\
\hline & {$[0.25]$} & {$[0.28]$} & & {$[0.14]$} & {$[0.17]$} \\
\hline \multirow[t]{2}{*}{$B M$} & 0.00 & 0.00 & $B M$ & 0.00 & 0.00 \\
\hline & {$[1.07]$} & {$[1.00]$} & & {$[1.03]$} & {$[0.96]$} \\
\hline
\end{tabular}




\begin{tabular}{|c|c|c|c|c|c|}
\hline PREEXRET & $\begin{array}{l}-0.01 \\
{[-0.19]}\end{array}$ & $\begin{array}{l}0.00 \\
{[0.07]}\end{array}$ & PREEXRET & $\begin{array}{l}-0.01 \\
{[-0.17]}\end{array}$ & $\begin{array}{l}0.01 \\
{[0.09]}\end{array}$ \\
\hline MOMENTUM & $\begin{array}{l}-0.01 \\
{[-0.88]}\end{array}$ & $\begin{array}{l}-0.00 \\
{[-0.47]}\end{array}$ & MOMENTUM & $\begin{array}{l}-0.01 \\
{[-0.92]}\end{array}$ & $\begin{array}{l}-0.00 \\
{[-0.49]}\end{array}$ \\
\hline Industry FE & No & Yes & & No & Yes \\
\hline Year FE & No & Yes & & No & Yes \\
\hline $\mathrm{N}$ & 3628 & 3628 & $\mathrm{~N}$ & 3628 & 3628 \\
\hline RSQ & 0.027 & 0.057 & RSQ & 0.026 & 0.055 \\
\hline adj. RSQ & 0.023 & 0.040 & adj. RSQ & 0.022 & 0.039 \\
\hline
\end{tabular}

Table 7 presents evidence on the additional factors that affect the effects of media co-coverage. In Column (1) and (2), I examine if the effects of co-coverage are stronger when the focal firm has higher uncertainty. A focal firm is regarded as having high uncertainty $(U N C=1)$ if its average analyst forecast dispersion is above the industry median, provided that there are on average more than 5 analysts providing forecasts over the benchmark window. Otherwise, it is considered as having low uncertainty $(U N C=0)$. In Column (3) and (4), I examine if the negative relationship between the co-covered firms' announcement returns can be mainly attributed to retail investors. I use the change in the abnormal retail dollar volume of the focal firm on the co-covered peer's earnings announcement day in the post-co-coverage period over the pre-co-coverage period to measure the extent to which retail investors' perceived relatedness between the two firms changes due to media co-coverage, with a more positive change indicating higher perceived relatedness in the post period. A focal firm is considered to have abnormally high retail activity on the peer's announcement day $(R E T A I L=1)$ if the change in its abnormal retail trading volume in the post-co-coverage period relative to the pre-co-coverage period is above the industry median, provided that there is non-zero retail trading over the benchmark window. Otherwise, the focal firm is regarded as having low retail activity $(R E T A I L=0)$. EXRET OWN is the focal firm's announcement excess return. EXRET P is the early-announcing peer's announcement excess return. AFTER (BEFORE) is an indicator variable that is equal to 1 if an observation is from the post- (pre-) co-coverage period, and 0 otherwise. EXRET is the focal firm's excess return on the peer's announcement day. SURP is the earnings surprise of the focal firm, scaled by lagged market capitalization. $L O G M K T C A P$ is the natural logarithm of the focal firm's market capitalization as of the end of the previous fiscal quarter. $A C C$ is the total accruals of the focal firm as of the end of the previous fiscal quarter. $B M$ is the book-to-market ratio of the focal firm as of the end of the previous fiscal quarter. PREEXRET is the cumulated market-adjusted excess return of the focal firm over a three-day window ending two days before its earnings announcement day. MOMENTUM is the cumulative market-adjusted excess return of the focal firm over a ninety-day window ending five days before its earnings announcement. Industry fixed effects are based on the focal firm's FF48 industry. Standard errors are clustered by firm and quarter. $* * *$, and $* * *$ represent significance levels at $10 \%, 5 \%$, and $1 \%$, respectively. 
TABLE 8

Alternative Explanations

Panel A. Placebo focal firms

\begin{tabular}{|c|c|c|c|c|c|c|}
\hline \multirow[t]{2}{*}{ Placebo focal firm is: } & \multicolumn{2}{|c|}{ Most similar firm } & \multicolumn{2}{|c|}{$\begin{array}{l}\text { Most similar firm in the same } \\
\text { size decile }\end{array}$} & \multicolumn{2}{|c|}{$\begin{array}{l}\text { Most similar firm in the same } \\
W S J \text { coverage decile }\end{array}$} \\
\hline & $(1)$ & (2) & (3) & (4) & $(5)$ & (6) \\
\hline (t-stats in brackets) & EXRET_OWN & EXRET_OWN & EXRET_OWN & EXRET_OWN & EXRET_OWN & EXRET_OWN \\
\hline \multirow{2}{*}{ EXRET_P $* A F T E R$} & 0.04 & 0.05 & 0.10 & 0.09 & -0.01 & -0.02 \\
\hline & {$[0.59]$} & {$[0.70]$} & [1.61] & {$[1.53]$} & {$[-0.08]$} & {$[-0.30]$} \\
\hline \multirow[t]{2}{*}{ EXRET_P * BEFORE } & -0.05 & -0.05 & 0.01 & 0.04 & 0.03 & -0.01 \\
\hline & {$[-1.10]$} & {$[-1.32]$} & {$[0.20]$} & [1.10] & {$[0.24]$} & {$[-0.05]$} \\
\hline \multirow[t]{2}{*}{ EXRET * AFTER } & -0.00 & 0.06 & 0.20 & 0.18 & 0.47 & 0.46 \\
\hline & {$[-0.02]$} & {$[0.29]$} & {$[1.18]$} & {$[0.90]$} & {$[1.19]$} & {$[0.96]$} \\
\hline \multirow[t]{2}{*}{ EXRET * BEFORE } & 0.13 & 0.16 & 0.31 & $0.40^{*}$ & 0.54 & 0.55 \\
\hline & {$[0.88]$} & {$[1.09]$} & {$[1.41]$} & {$[1.84]$} & {$[0.86]$} & {$[1.11]$} \\
\hline \multirow[t]{2}{*}{ AFTER } & 0.01 & 0.00 & -0.01 & $-0.01 *$ & -0.01 & -0.01 \\
\hline & {$[0.71]$} & {$[0.28]$} & {$[-1.65]$} & {$[-1.84]$} & {$[-0.71]$} & {$[-0.60]$} \\
\hline \multirow[t]{2}{*}{$S U R P$} & $1.11^{* *}$ & $1.07 * *$ & $1.89 * * *$ & $1.72 * * *$ & $0.67 * * *$ & $0.63 * *$ \\
\hline & {$[2.30]$} & {$[2.21]$} & [3.17] & {$[2.76]$} & {$[2.72]$} & {$[2.68]$} \\
\hline \multirow[t]{2}{*}{$L O G \_M K T C A P$} & $-0.00 *$ & -0.00 & $-0.01 * *$ & -0.00 & 0.01 & 0.01 \\
\hline & {$[-1.75]$} & {$[-1.24]$} & {$[-2.44]$} & {$[-1.35]$} & {$[1.34]$} & {$[1.04]$} \\
\hline \multirow[t]{2}{*}{$A C C$} & -0.02 & -0.16 & -0.18 & -0.15 & -0.06 & -0.14 \\
\hline & {$[-0.08]$} & {$[-0.94]$} & {$[-1.27]$} & {$[-1.43]$} & {$[-0.26]$} & {$[-0.43]$} \\
\hline \multirow[t]{2}{*}{$B M$} & -0.00 & 0.00 & -0.01 & -0.00 & -0.00 & -0.00 \\
\hline & {$[-0.31]$} & {$[0.20]$} & {$[-0.84]$} & {$[-0.37]$} & {$[-0.09]$} & {$[-0.19]$} \\
\hline \multirow[t]{2}{*}{ PREEXRET } & -0.07 & -0.10 & $-0.17 * *$ & $-0.19 * *$ & 0.00 & -0.03 \\
\hline & {$[-0.71]$} & {$[-1.21]$} & {$[-2.12]$} & {$[-2.05]$} & {$[0.03]$} & {$[-0.34]$} \\
\hline \multirow[t]{2}{*}{ MOMENTUM } & -0.01 & 0.02 & 0.02 & 0.02 & $0.06^{* * *}$ & $0.05 * * *$ \\
\hline & {$[-0.27]$} & {$[0.65]$} & {$[1.10]$} & {$[1.07]$} & {$[3.00]$} & {$[3.18]$} \\
\hline Industry FE & No & Yes & No & Yes & No & Yes \\
\hline
\end{tabular}




\begin{tabular}{llccccc}
\hline Year FE & No & Yes & No & Yes & No & \\
N & & & & & & \\
RSQ & 1000 & 1000 & 1056 & 1056 & 298 & 298 \\
adj. RSQ & 0.030 & 0.123 & 0.074 & 0.131 & 0.095 & 0.217 \\
\hline
\end{tabular}


Panel B. Placebo news articles

\begin{tabular}{|c|c|c|}
\hline \multirow[b]{2}{*}{ (t-stats in brackets) } & (1) & $(2)$ \\
\hline & EXRET_OWN & EXRET_OWN \\
\hline \multirow[t]{2}{*}{$E X R E T \_P * A F T E R$} & -0.18 & -0.21 \\
\hline & {$[-1.38]$} & {$[-1.29]$} \\
\hline \multirow[t]{2}{*}{$E X R E T \_P * B E F O R E$} & -0.02 & -0.07 \\
\hline & {$[-0.21]$} & {$[-0.51]$} \\
\hline \multirow[t]{2}{*}{ EXRET * AFTER } & 0.07 & 0.29 \\
\hline & {$[0.24]$} & {$[0.56]$} \\
\hline \multirow[t]{2}{*}{$E X R E T *$ BEFORE } & $0.41 * *$ & $0.46^{* *}$ \\
\hline & {$[2.45]$} & {$[2.29]$} \\
\hline \multirow[t]{2}{*}{ AFTER } & -0.01 & -0.01 \\
\hline & {$[-1.01]$} & {$[-0.93]$} \\
\hline \multirow[t]{2}{*}{ SURP } & $1.13 * * *$ & $1.12 *$ \\
\hline & {$[2.73]$} & {$[2.00]$} \\
\hline \multirow[t]{2}{*}{$L O G \_M K T C A P$} & 0.00 & 0.00 \\
\hline & {$[0.55]$} & {$[1.34]$} \\
\hline \multirow[t]{2}{*}{$A C C$} & $0.13 * *$ & $0.18^{* * *}$ \\
\hline & {$[2.32]$} & {$[2.72]$} \\
\hline \multirow[t]{2}{*}{$B M$} & 0.01 & 0.02 \\
\hline & {$[0.63]$} & {$[1.02]$} \\
\hline \multirow[t]{2}{*}{ PREEXRET } & -0.15 & -0.08 \\
\hline & {$[-0.81]$} & {$[-0.38]$} \\
\hline \multirow[t]{2}{*}{ MOMENTUM } & 0.01 & 0.01 \\
\hline & [0.29] & {$[0.21]$} \\
\hline Industry FE & No & Yes \\
\hline Year FE & No & Yes \\
\hline $\mathrm{N}$ & 258 & 258 \\
\hline RSQ & 0.079 & 0.191 \\
\hline adj. RSQ & 0.038 & 0.014 \\
\hline
\end{tabular}

Panel C. Risk-based explanation

\begin{tabular}{|c|c|c|c|c|}
\hline \multirow[b]{3}{*}{ (t-stats in brackets) } & \multicolumn{2}{|c|}{$S A M E S I G N=1$} & \multicolumn{2}{|c|}{$S A M E S I G N=0$} \\
\hline & (1) & (2) & (3) & (4) \\
\hline & EXRET_OWN & EXRET_OWN & EXRET_OWN & EXRET_OWN \\
\hline \multirow[t]{2}{*}{$E X R E T \_P * A F T E R$} & $-0.05 *$ & $-0.05 * *$ & -0.05 & -0.07 \\
\hline & {$[-2.00]$} & {$[-2.50]$} & {$[-0.57]$} & {$[-0.96]$} \\
\hline \multirow[t]{2}{*}{ EXRET_P $*$ BEFORE } & $0.09 * * *$ & $0.07 * *$ & -0.04 & -0.04 \\
\hline & {$[2.84]$} & {$[2.45]$} & {$[-0.85]$} & {$[-0.79]$} \\
\hline \multirow[t]{2}{*}{ EXRET * AFTER } & 0.09 & 0.08 & 0.08 & 0.08 \\
\hline & {$[0.69]$} & {$[0.62]$} & {$[0.36]$} & {$[0.45]$} \\
\hline$E X R E T * B E F O R E$ & -0.17 & -0.17 & $0.39 * *$ & $0.37 * *$ \\
\hline
\end{tabular}




\begin{tabular}{lllll}
\hline & {$[-1.30]$} & {$[-1.24]$} & {$[2.64]$} & {$[2.31]$} \\
AFTER & $0.01^{*}$ & 0.01 & 0.00 & 0.00 \\
& {$[1.76]$} & {$[1.30]$} & {$[0.39]$} & {$[0.07]$} \\
SURP & $1.59^{* *}$ & $1.83^{* * *}$ & 0.75 & 0.78 \\
& {$[2.64]$} & {$[2.75]$} & {$[1.49]$} & {$[1.45]$} \\
LOG_MKTCAP & 0.00 & 0.00 & $0.00^{* *}$ & $0.00^{* *}$ \\
& {$[0.82]$} & {$[1.51]$} & {$[2.06]$} & {$[2.06]$} \\
ACC & -0.02 & -0.01 & 0.09 & 0.08 \\
& {$[-0.23]$} & {$[-0.10]$} & {$[1.59]$} & {$[1.11]$} \\
BM & 0.01 & 0.01 & 0.00 & 0.00 \\
& {$[1.50]$} & {$[1.27]$} & {$[0.38]$} & {$[0.64]$} \\
PREEXRET & 0.02 & 0.02 & -0.06 & -0.04 \\
& {$[0.29]$} & {$[0.36]$} & {$[-0.71]$} & {$[-0.43]$} \\
MOMENTUM & -0.01 & -0.01 & 0.00 & 0.01 \\
& {$[-1.44]$} & {$[-1.11]$} & {$[0.27]$} & {$[0.48]$} \\
Industry FE & No & Yes & No & Yes \\
Year FE & No & Yes & No & Yes \\
& & & & \\
N & 2745 & 2745 & 883 & 883 \\
RSQ & 0.031 & 0.067 & 0.046 & 0.124 \\
adj. RSQ & 0.027 & 0.047 & 0.034 & 0.063 \\
\hline
\end{tabular}

Table 8 tabulates results from tests designed to rule out alternative explanations to the negative return predictability in two co-covered firms' earnings announcement returns. Panel A presents the estimation results from regressing the earnings announcement return of a placebo firm to the focal firm in the main analysis on the announcement return of the co-covered peer in both the post- and pre-co-coverage period, along with the control variables. In Column (1) and (2), the placebo firm is the most similar firm to the focal firm in terms of Hoberg and Phillips (2010, 2016)'s product similarity score. In Column (3) and (4), the placebo firm is the most similar firm to the focal firm, provided that the two are in the same size decile as measured by lagged market capitalization. In Column (5) and (6), the placebo firm is the most similar firm to the focal firm, provided that the two are in the same WSJ coverage decile. Panel B presents the estimation results from regressing the earnings announcement return of the focal firm on the co-covered peer's announcement return in post and pre period defined by the publication date of a placebo article. For each article in the main sample, I identify a corresponding placebo article where (1) it covers the earnings announcement of the same firm as the original article; (2) the focal firm and the co-covered peer are not mentioned in the placebo article (while they are mentioned in the original article) and (3) the placebo article is published at least 400 days after the publication date of the original article so that there is no overlap between the pre-co-coverage window of the placebo article and the post-co-coverage window of the original article. If there are multiple placebo articles that satisfy these criteria, I keep the earliest article. Panel C presents the estimation results from regressing the earnings announcement return of the focal firm on the co-covered peer's announcement return in both the pre- and post-co-coverage period using subsamples where the earnings surprise of the co-covered peer and the expected earnings surprise of the focal firm have the same versus different signs. The expected earnings surprise of the focal firm is estimated as the predicted value from regressing the focal firm's earnings surprise on the peer's earnings surprise, estimated separately for the pre- and post-co-coverage period. EXRET_OWN is the focal firm's announcement excess return. EXRET_P is the early-announcing peer's announcement excess return. AFTER (BEFORE) is an indicator variable that is equal to 1 if an observation is from the post- (pre-) co-coverage period, and 0 otherwise. EXRET is the focal firm's excess return on the peer's announcement day. SURP is the earnings surprise of the focal firm, scaled by lagged market capitalization. $L O G_{-} M K T C A P$ is the natural logarithm of the focal 
firm's market capitalization as of the end of the previous fiscal quarter. $A C C$ is the total accruals of the focal firm as of the end of the previous fiscal quarter. $B M$ is the book-to-market ratio of the focal firm as of the end of the previous fiscal quarter. PREEXRET is the cumulated market-adjusted excess return of the focal firm over a three-day window ending two days before its earnings announcement day. MOMENTUM is the cumulative market-adjusted excess return of the focal firm over a ninety-day window ending five days before its earnings announcement. Industry fixed effects are based on the focal firm's FF48 industry. Standard errors are clustered by firm and quarter. *, **, and *** represent significance levels at $10 \%, 5 \%$, and $1 \%$, respectively. 